\title{
Adaptive Plasticity in Tachykinin and Tachykinin Receptor Expression after Focal Cerebral Ischemia Is Differentially Linked to GABAergic and Glutamatergic Cerebrocortical Circuits and Cerebrovenular Endothelium
}

\author{
Ralf K. Stumm, ${ }^{1}$ Carsten Culmsee, ${ }^{2}$ Martin K.-H. Schäfer, ${ }^{1}$ Josef Krieglstein, ${ }^{2}$ and Eberhard Weihe ${ }^{1}$ \\ ${ }^{1}$ Department of Molecular Neuroscience, Institute of Anatomy and Cell Biology, Clinics of Philipps University Marburg, \\ 35033 Marburg, Germany, and 2Institute of Pharmacology and Toxicology, Philipps University Marburg, 35037 Marburg, \\ Germany
}

To test the hypothesis of an involvement of tachykinins in destabilization and hyperexcitation of neuronal circuits, gliosis, and neuroinflammation during cerebral ischemia, we investigated cell-specific expressional changes of the genes encoding substance $\mathrm{P}(\mathrm{SP})$, neurokinin $\mathrm{B}(\mathrm{NKB})$, and the tachykinin/ neurokinin receptors (NK1, NK2, and NK3) after middle cerebral artery occlusion (MCAO) in the rat. Our analysis by quantitative in situ hybridization, immunohistochemistry, and confocal microscopy was concentrated on cerebrocortical areas that survive primary infarction but undergo secondary damage. Here, SP-encoding preprotachykinin-A and NK1 mRNA levels and SP-like immunoreactivity were transiently increased in GABAergic interneurons at $2 \mathrm{~d}$ after MCAO. Coincidently, MCAO caused a marked expression of SP and NK1 in a subpopulation of glutamatergic pyramidal cells, and in some neurons SP and NK1 mRNAs were coinduced. Elevated levels of the NKBencoding preprotachykinin-B mRNA and of NKB-like immunore-

Substance P (SP) and neurokinin A (NKA), the endogenous ligands preferentially acting at the neurokinin-1 (NK1) and NK2 tachykinin receptors, respectively, are encoded by the preprotachykinin-A (PPT-A) gene (Sasai and Nakanishi, 1989; Carter and Krause, 1990; Hershey et al., 1991). Neurokinin B (NKB) binds at the NK3 receptor and is encoded by the PPT-B gene (Bonner et al., 1987; Shigemoto et al., 1990). The PPT and $\mathrm{NK}$ receptor genes are expressed in specific neuronal pathways of the rodent and primate CNS and peripheral nervous system (Ljungdahl et al., 1978; Warden and Young, 1988; Maeno et al., 1993; Nakaya et al., 1994; Ding et al., 1996; Shughrue et al., 1996; Hurd et al., 1999; Mileusnic et al., 1999).

In the cerebral cortex, SP and NK1 are thought to modulate specifically the communication between GABAergic interneu-

Received July 6, 2000; revised Oct. 25, 2000; accepted Nov. 3, 2000.

This work was supported by grants from the Deutsche Forschungsgemeinschaft (SFB 297 and Forschergruppe Neuroprotektion) and from the Volkswagen-Stiftung. We thank Marion Hainmüller and Elke Rodenberg for technical assistance and Heidemarie Schneider for photodocumentation. We are grateful to Dr. J. E. Krause for kindly providing vectors containing the preprotachykinin-A, NK1, NK2, and NK3 cDNA fragments as well as the antibody against the protein precursor of neurokinin B. We thank Drs. R. L. Eskay, M. Loos, and R. Shigemoto for the generous gifts of the antibodies against substance $\mathrm{P}, \mathrm{NK} 1$, and $\mathrm{C} 1 \mathrm{q}$, respectively.

Correspondence should be addressed to Dr. Eberhard Weihe, Department of Molecular Neuroscience, Institute of Anatomy and Cell Biology, Philipps University Marburg, Robert-Koch-Straße 6, 35033 Marburg, Germany. E-mail: weihe@mailer. uni-marburg.de.

Copyright (C) 2001 Society for Neuroscience $0270-6474 / 01 / 210798-14 \$ 15.00 / 0$ activity at 2 and $7 \mathrm{~d}$ after MCAO were confined to GABAergic interneurons. In parallel, the expression of NK3 was markedly downregulated in pyramidal neurons. MCAO caused transient NK1 expression in activated cerebrovenular endothelium within and adjacent to the infarct. NK1 expression was absent from activated astroglia or microglia. The differential ischemia-induced plasticity of the tachykinin system in distinct inhibitory and excitatory cerebrocortical circuits suggests that it may be involved in the balance of endogenous neuroprotection and neurotoxicity by enhancing GABAergic inhibitory circuits or by facilitating glutamate-mediated hyperexcitability. The transient induction of NK1 in cerebrovenular endothelium may contribute to ischemiainduced edema and leukocyte diapedesis. Brain tachykinin receptors are proposed as potential drug targets in stroke.

Key words: neuropeptide; stroke; inflammation; blood-brain barrier; astrocyte; neuroimmune rons (Kaneko et al., 1998). SP depolarizes interneurons and was suggested to hyperpolarize principal neurons indirectly by releasing GABA from interneurons (Maubach et al., 1998). In contrast, NK2 expression in the forebrain is virtually undetectable (Whitty et al., 1995), and the function of NK2 in the cerebral cortex is unclear. By acting on NK3, NKB appears to influence specifically glutamatergic pyramidal neurons in the cerebral cortex with possible convulsive effects (Kaneko et al., 1998; Maubach et al., 1998).

The importance of the cerebrocortical tachykinin system in experimental seizure and excitotoxicity is currently emerging. SP is critically involved in the maintenance of status epilepticus, and PPT-A-deficient mice are resistant to kainate-induced seizures as well as the kainate-induced neuronal death (Liu et al., 1999). An NK1 antagonist reduces excitotoxin-induced seizures (Zachrisson et al., 1998). Experimental seizures enhance hippocampal PPT-B expression (Marksteiner et al., 1992) and reduce NK3 expression in the cerebral cortex (Roder et al., 1994).

In addition, SP is a known mediator of neurogenic inflammation that acts on NK1 receptors of endothelial and possibly inflammatory cells in peripheral tissues (Bowden et al., 1994; Weihe et al., 1994; Saban et al., 1997; Holzer, 1998; Marchand et al., 1998; Di Sebastiano et al., 1999; Quinlan et al., 1999b). Recently, it has been suggested that NK1 receptors modulate glial and inflammatory responses in the brain because inflamma- 
tory reactions and astrocyte activation during trypanosomainduced meningoencephalitis are ameliorated by an NK1 receptor antagonist (Kennedy et al., 1997). Trans-section of the optical nerve induces binding sites for SP in reactive astrocytes (Mantyh et al., 1989).

Ischemic brain injury results from neuronal hyperexcitation and destabilization of the cerebrocortical neuronal network and has an inflammatory component (Dirnagl et al., 1999; Lee et al., 1999; del Zoppo et al., 2000). With regard to the apparent involvement of tachykinins in excitotoxic neuronal disorders and neuroinflammatory brain injury, we hypothesized that tachykinins and tachykinin receptors are important in the pathophysiology of stroke. Therefore, we explored the specific plasticity of the expression of the PPT and NK receptor genes during the course of permanent focal cerebral ischemia, especially in relation to glutamatergic excitatory and GABAergic inhibitory neurons, and investigated whether ischemia alters NK1 receptor expression in endothelial, glial, or infiltrating inflammatory cells.

\section{MATERIALS AND METHODS}

Animal model of focal cerebral ischemia. Permanent unilateral middle cerebral artery occlusion (MCAO) was performed in male Long-Evans rats (Mollegaard) as introduced by Tamura et al. (1981) with modifications (Culmsee et al., 1999). The animals were maintained under controlled light and environmental conditions (12/12 hr dark/light cycle; $23 \pm 1{ }^{\circ} \mathrm{C} ; 55 \%$ relative humidity) and were given food (Altromin, Lage, Germany) and water ad libitum. During the surgical procedure, they were anesthetized with halothane $\left[1.5 \%\right.$ in a mixture of $\left.\mathrm{O}_{2} / \mathrm{N}_{2} \mathrm{O}(30: 70)\right]$. An incision was made through the left temporalis muscle perpendicular to a line between the external auditory canal and the lateral canthus of the left eye. Under direct visualizaton with the surgical microscope, a burr hole was made with a handheld drill to expose the left middle cerebral artery. After the dura was rejected, the left middle cerebral artery was occluded by microbipolar electrocoagulation. The occlusion step was omitted in sham-operated animals. After occlusion or sham operation, the incisions in the left temporal muscle and skin were closed to guarantee the function of the temporal muscle for the uptake of food after surgery. During the surgical procedure, the body temperature was maintained at $37 \pm 0.5^{\circ} \mathrm{C}$ by means of a heating pad. To prevent a decrease of body temperature, the animals were kept at an environmental temperature of $30^{\circ} \mathrm{C}$ up to $2 \mathrm{hr}$ after MCAO.

Experimental groups and tissue preparation. All animals were anesthetized (400 mg/kg chloral hydrate, i.p.) before removal of brain or perfusion. For quantitative radioactive in situ hybridization, brains were collected from six decapitated rats at $6 \mathrm{hr}, 2 \mathrm{~d}$, and $7 \mathrm{~d}$ after sham operation and MCAO. For double in situ hybridization, two animals were prepared $2 \mathrm{~d}$ after MCAO and after sham operation. The brains were rapidly removed, frozen in 2-methylbutane (Fluka, Buchs, Switzerland) at $-30^{\circ} \mathrm{C}$, and stored at $-70^{\circ} \mathrm{C}$. For immunohistochemistry, two animals at $6 \mathrm{hr}, 2 \mathrm{~d}$, and $7 \mathrm{~d}$ after MCAO and after sham operation were perfused transcardially with $10 \mathrm{~mm}$ PBS containing $20 \mathrm{U} / \mathrm{ml}$ heparin followed by Bouin Hollande fixative. The brains were removed, dissected into an anterior, middle, and posterior part, and immersed overnight in Bouin Hollande fixative. After fixation the tissue was extensively washed in $70 \%$ 2-propanol and processed for routine paraffin embedding.

Single enzymatic immunohistochemistry. Previously well characterized antibodies were used. An antiserum against the rat NK1 was generously provided by R. Shigemoto (Shigemoto et al., 1993) and used at $5 \mu \mathrm{g} / \mathrm{ml}$. Antisera directed against SP (a gift of R. L. Eskay, National Institute on Drug Abuse, Bethesda, MD) and against a 30-residue fragment of the protein precursor to NKB provided by J. E. Krause (Lucas et al., 1992) were used at 1:12,000. An antibody against P-selectin (CD62-P), a marker of activated venular endothelium after MCAO (Suzuki et al., 1998), was purchased from PharMingen (San Diego, CA) and used at 1:500. Immunohistochemistry was performed as described (Rohrenbeck et al., 1999) with few modifications. Sections of $10 \mu \mathrm{m}$ thickness were mounted on adhesive slides. After deparaffinization and blocking of endogenous peroxidase with $0.5 \%$ perhydrol in methanol, sections were heated at $92-95^{\circ} \mathrm{C}$ for $15 \mathrm{~min}$ in $0.01 \mathrm{M}$ citrate buffer, $\mathrm{pH}$ 6.0. After incubation for $30 \mathrm{~min}$ in $50 \mathrm{~mm}$ PBS containing $5 \%$ bovine serum albumin, nonspecific binding of avidin-biotin was blocked by the Biotin/Avidin Blocking Kit

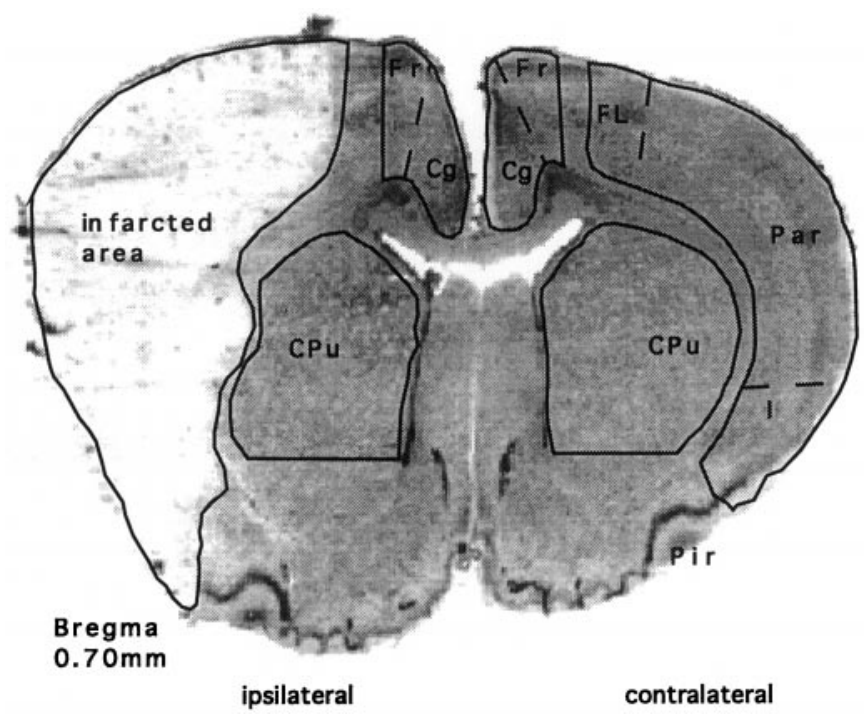

Figure 1. Low-power micrograph of a cresyl violet-stained 20 - $\mu$ m-thick frozen coronal section through a rat forebrain $2 \mathrm{~d}$ after MCAO. The pale infarcted area is clearly delineated and includes the forelimb $(F L)$ and parietal (Par) areas of the cortex and large parts of the insular $(I)$ and piriform (Pir) cortex. The caudate-putamen $(C P u)$ is only infarcted in its exterior part. The cingulate $(C g)$ and frontal $(F r)$ cortex is not infarcted. Note the swelling of the infarcted hemisphere as compared with the contralateral hemisphere.

(Vector Laboratories, Burlingame, CA). Sections were incubated with primary antibodies overnight at $18^{\circ} \mathrm{C}$ followed by $2 \mathrm{hr}$ at $37^{\circ} \mathrm{C}$. For negative controls, primary antibodies were omitted. After several washes in distilled water followed by rinsing in $50 \mathrm{mM} \mathrm{PBS}$, species-specific biotinylated secondary antibodies (Dianova, Hamburg, Germany) were applied for $45 \mathrm{~min}$ at $37^{\circ} \mathrm{C}$. After another series of washes, sections were incubated for $30 \mathrm{~min}$ with the $\mathrm{ABC}$ reagents (Vectastain $\mathrm{ABC}-\mathrm{Kit}$; Vector Laboratories) followed by a nickel-enhanced diaminobenzidine reaction $(0.125 \mu \mathrm{g} / \mathrm{ml}$ diaminobenzidine and $0.75 \mu \mathrm{g} / \mathrm{ml}$ ammonium nickel sulfate) for $10 \mathrm{~min}$ at room temperature. Sections were analyzed and photographed with an Olympus AX70 microscope.

Confocal laser-scanning double-immunofluorescence microscopy for NK1 and markers for astrocytes and microglial cells. Doubleimmunofluorescence detection of NK1 and glial fibrillary acidic protein (GFAP) as a marker for astrocytes or the complement factor C1q, a recently established marker for microglia (Dietzschold et al., 1995; Schafer et al., 2000), was performed as follows. Sections were incubated overnight at room temperature with a mixture of a polyclonal rabbit anti-NK1 (Chemicon, Temecula, CA) and a goat anti-mouse C1q antibody (IgG fraction; diluted 1:40) (Schwaeble et al., 1995) or a polyclonal guinea pig anti-GFAP antiserum (1:400) (Weihe et al., 1993). C1q- and GFAP-like immunoreactivities were visualized with indocarbocyanineconjugated anti-goat and anti-guinea pig IgG (Dianova) that was diluted 1:200 and applied for $45 \mathrm{~min}$ at $37^{\circ} \mathrm{C}$, resulting in a red-orange fluorescence labeling. NK1-like immunoreactivity (NK1-ir) was visualized with biotinylated IgG (Dianova) that was diluted 1:200 and applied for $45 \mathrm{~min}$ at $37^{\circ} \mathrm{C}$, followed by incubation with Alexis 488-conjugated streptavidin (MoBiTec, Göttingen, Germany) for $2 \mathrm{hr}$ at $37^{\circ} \mathrm{C}$, resulting in a green fluorescence. Sections were analyzed with the Olympus Fluoview confocal laser-scanning microscope (Olympus Optical, Hamburg, Germany), and false-color confocal images were printed with a digital color printer (Sony, Tokyo, Japan).

Probes used in in situ hybridization histochemistry. Plasmid vector constructs containing cDNA fragments of the rat PPT-A gene (Carter and Krause, 1990) and of the three tachykinin receptors NK1 (nucleotides -555 to -72 ) (Hershey et al., 1991), NK2 (nucleotides 260-846) (Sasai and Nakanishi, 1989), and NK3 (nucleotides 1256-1585) (Shigemoto et al., 1990) were provided by J. E. Krause. The PPT-A-specific cDNA was homologous to the coding region of rat $\beta$-PPT-A mRNA but also shared homology to the alternatively spliced mRNAs $\alpha$ and $\gamma$ (Carter and Krause, 1990). Reverse transcription-PCR cloning was used to obtain specific cDNA fragments for the following sequences: rat PPT-B (Bon- 
Figure 2. Spatiotemporal patterns of changes in cerebral PPT-A $(A-D)$ and NK1 mRNA $(E-H)$ expression after MCAO. Low-power micrographs of x-ray autoradiograms after in situ hybridization of coronal sections through the forebrain are shown. The lateral borders of the infarcted area at each stage after MCAO are marked by $a r-$ rowheads. For identification of the different brain regions see Figure 1. $A, E$, PPT-A mRNA and NK1 mRNA levels of expression, respectively, are low in the ipsilateral and contralateral cortex of a rat $2 \mathrm{~d}$ after sham operation. $B-D$, Note a marked increase in PPT-A mRNA levels $(C$, arrows) in noninfarcted ipsilateral cingulate, frontal, insular, and piriform cortical areas at $2 \mathrm{~d}$ after MCAO. PPT-A mRNA is completely lost in the infarcted cortex $(B-D)$. In the dorsal caudate-putamen at $6 \mathrm{hr}$ after MCAO $(B)$, there is a marked increase in PPT-A mRNA levels on the ipsilateral side and a less marked increase on the contralateral side as compared with levels in $A$. [Note that the contralateral increase seen in this animal was not seen in all animals of this experimental group; in the dorsal caudateputamen, there was no statistically significant difference between contralateral and sham PPT-A mRNA levels (see Table 1).] At $2 \mathrm{~d}$ after $\mathrm{MCAO}(C)$, PPT-A mRNA is lost in the infarcted lateral part of the caudate-putamen and decreased in the noninfarcted ipsilateral caudate-putamen as compared with the sham animal $(A)$. At $7 \mathrm{~d}$ after MCAO $(D)$, PPT-A mRNA levels in the noninfarcted caudate-putamen return to the levels seen after sham treatment $(A)$. $F-H$, At 2 d after MCAO $(G)$ but not at 6 hr $(F)$ or $7 \mathrm{~d}(H)$ after MCAO, NK1 mRNA expression is induced in a distinct band $(G$, arrow) of the ipsilateral cingulate and frontal cortex as compared with a shamoperated animal $(E)$ (for high magnification see Fig. 3). NK1 mRNA is present in the meningeal circumference of the infarcted area at $2 \mathrm{~d}(G)$ and at $7 \mathrm{~d}(H)$ after MCAO but is not present at $6 \mathrm{hr}$ after MCAO $(F)$ or in the sham-treated rat $(E)$. Note the presence of some NK1 mRNA expression in the infarcted area at all stages after MCAO (for high magnification see Fig. 5). Sham-operated animals $2 \mathrm{~d}$ after surgery $(A, E)$ are representative of the shamoperated animals $6 \mathrm{hr}$ and $7 \mathrm{~d}$ after surgery. Exposure times: $A-D, 24 \mathrm{hr} ; E-H, 72 \mathrm{hr}$.

\section{PPT-A mRNA}
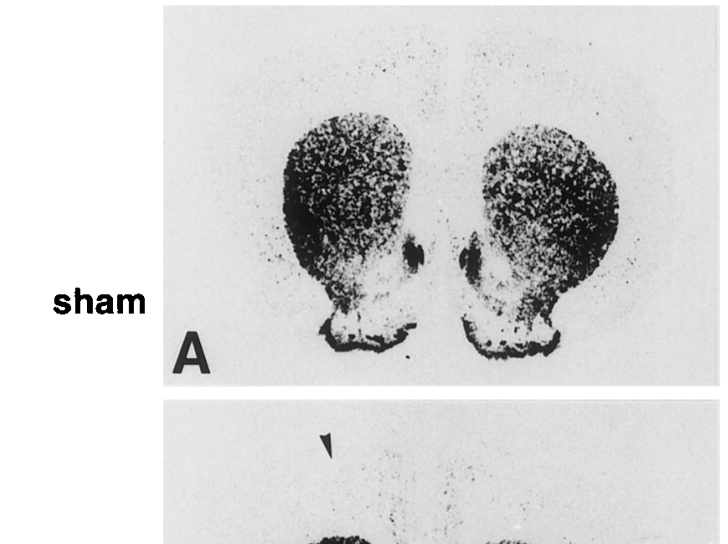

MCAO

Y
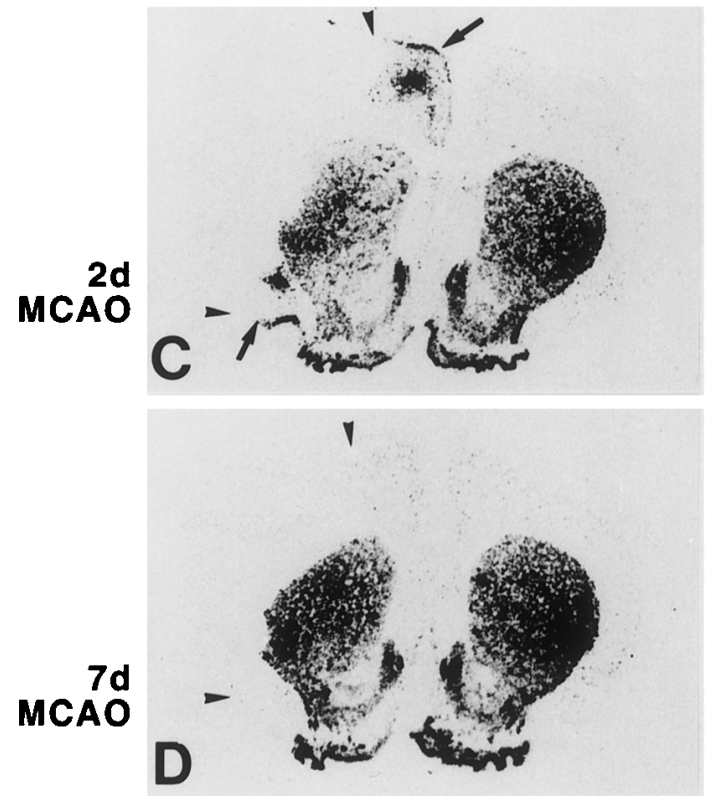

NK1 mRNA

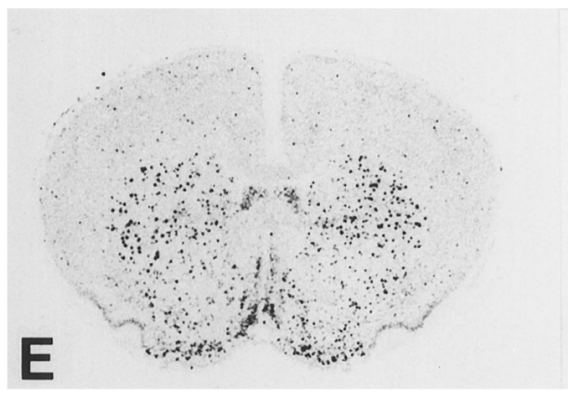

1
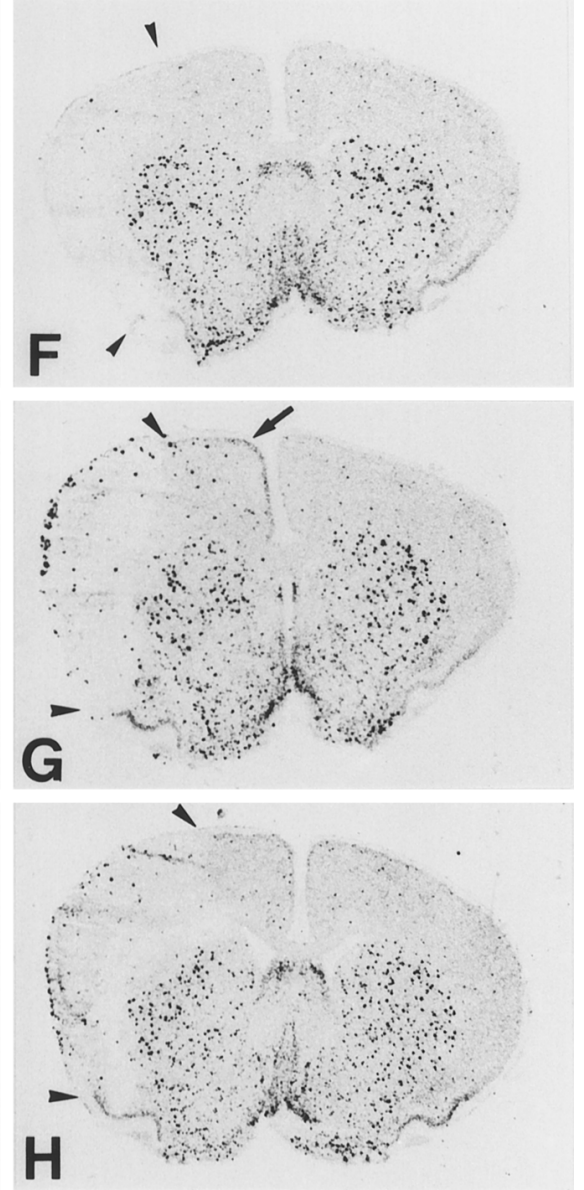

ner et al., 1987) (nucleotides 283-665), rat glutamic acid decarboxylase ( $M_{\mathrm{r}}$ 67,000; GAD; EC 4.1.1.15) (Wyborski et al., 1990) (nucleotides 1200-2041), and rat phosphate-activated glutaminase (PAG; EC 3.5.1.2) (Shapiro et al., 1991) (nucleotides 417-1304). GAD is an extensively used marker for GABAergic neurons, both on the protein and on the mRNA level. PAG is a an established marker of glutamatergic cerebrocortical neurons on the protein level (Kaneko and Mizuno, 1994). On the mRNA level PAG is expressed at high levels in cerebrocortical pyramidal neurons but not in GAD-containing neurons (Najlerahim et al., 1990).

The amplified cDNA fragments were subcloned into the pGEM-T vector (Promega, Madison, WI); their sequence identity was confirmed by double-strand DNA sequencing. Riboprobes in antisense and sense orientation were generated from linearized vector constructs by in vitro transcription (Melton et al., 1984) using the appropriate RNA polymerases and ${ }^{35} \mathrm{~S}-\mathrm{UTP},{ }^{35} \mathrm{~S}-\mathrm{CTP}$, or digoxigenin-UTP as label. Radioactive riboprobes specific for PPT-A, PPT-B, GAD, and PAG were singlelabeled $\left({ }^{35} \mathrm{~S}-\mathrm{UTP}\right)$; those for NK1, NK2, and NK3 were double-labeled $\left({ }^{35} \mathrm{~S}\right.$-UTP and ${ }^{35} \mathrm{~S}$-CTP $)$. After transcription, the probes were subjected to mild alkaline hydrolysis as described (Angerer et al., 1987).

In situ hybridization histochemistry. Radioactive in situ hybridization was performed as described previously (Schafer et al., 1993). Frozen serial sections were cut at $20 \mu \mathrm{m}$ thickness on a cryostat, thaw-mounted on adhesive slides, and stored at $-70^{\circ} \mathrm{C}$. All of the following steps were performed at room temperature. The frozen sections were thawed for 15 min before fixation in phosphate-buffered $4 \%$ paraformaldehyde for 60 $\mathrm{min}$. Three washes in $50 \mathrm{~mm}$ PBS, $\mathrm{pH} 7.4$, for $10 \mathrm{~min}$ each were performed before the slides were transferred for $10 \mathrm{~min}$ to $0.4 \%$ Triton X-100. The slides were rinsed in distilled water and transferred to $0.1 \mathrm{M}$ triethanolamine, pH 8.0 (Sigma, Deisenhofen, Germany). Acetic anhydrate (Sigma) was added under stirring to a final concentration of $0.25 \%(\mathrm{v} / \mathrm{v})$, and sections were further incubated for $10 \mathrm{~min}$. The slides were rinsed twice in $50 \mathrm{~mm}$ PBS, pH 7.4, for $10 \mathrm{~min}$ each before dehydration in 50 and $70 \%$ 2-propanol. The air-dried sections were stored at $-20^{\circ} \mathrm{C}$. For hybridization, riboprobes were diluted in hybridization buffer $\left(3 \times \mathrm{SSC}, 50 \mathrm{~mm} \mathrm{NaPO}_{4}, 10\right.$ 
Table 1. Influence of MCAO on PPT-A and NK1 mRNA levels in cerebral cortex and caudate-putamen

\begin{tabular}{|c|c|c|c|c|c|}
\hline & & \multicolumn{2}{|l|}{ PPT-A } & \multicolumn{2}{|l|}{ NK1 } \\
\hline & & Sham & MCAO & Sham & MCAO \\
\hline \multirow{3}{*}{$\begin{array}{l}\mathrm{Cg}, \mathrm{Fr} \\
\text { (ipsi) }\end{array}$} & $6 \mathrm{hr}$ & $48.9 \pm 11.9$ & $52.9 \pm 35.6$ & $31.0 \pm 11.4$ & $25.4 \pm 12.9$ \\
\hline & $2 \mathrm{~d}$ & $51.6 \pm 24.0$ & $436.0 \pm 241.3^{*}(+744 \%)$ & $36.9 \pm 12.3$ & $175.7 \pm 89.7^{*}(+\mathbf{3 7 6} \%)$ \\
\hline & $7 \mathrm{~d}$ & $38.7 \pm 12.1$ & $63.3 \pm 27.2$ & $26.8 \pm 5.6$ & $53.0 \pm 28.3$ \\
\hline \multirow{3}{*}{$\begin{array}{l}\mathrm{Cg}, \mathrm{Fr} \\
\text { (contra) }\end{array}$} & $6 \mathrm{hr}$ & $45.3 \pm 12.7$ & $46.9 \pm 30.2$ & $33.2 \pm 16.1$ & $39.1 \pm 24.7$ \\
\hline & $2 \mathrm{~d}$ & $44.7 \pm 19.9$ & $31.6 \pm 13.3$ & $36.6 \pm 10.0$ & $43.2 \pm 27.7$ \\
\hline & $7 \mathrm{~d}$ & $39.4 \pm 14.6$ & $54.1 \pm 17.6$ & $30.2 \pm 6.6$ & $47.4 \pm 27.8$ \\
\hline \multirow{3}{*}{$\begin{array}{l}\text { FL, Par, I } \\
\text { (contra) }\end{array}$} & $6 \mathrm{hr}$ & $16.2 \pm 7.1$ & $29.6 \pm 16.2$ & $42.2 \pm 27.7$ & $31.9 \pm 17.1$ \\
\hline & $2 \mathrm{~d}$ & $19.8 \pm 7.9$ & $17.5 \pm 7.8$ & $52.5 \pm 13.0$ & $51.2 \pm 30.3$ \\
\hline & $7 \mathrm{~d}$ & $19.0 \pm 10.7$ & $17.0 \pm 4.8$ & $49.5 \pm 23.7$ & $83.7 \pm 50.5$ \\
\hline \multirow{3}{*}{$\begin{array}{l}\mathrm{CPu} \\
\text { (ipsi) }\end{array}$} & $6 \mathrm{hr}$ & $1683 \pm 71.4$ & $1996 \pm 223.2 *(+\mathbf{1 8 . 5 \%})$ & $218.7 \pm 18.7$ & $190.9 \pm 96.5$ \\
\hline & $2 \mathrm{~d}$ & $1666 \pm 86.0$ & $1026 \pm 292.6^{* *}(\mathbf{- 3 8 . 4 \% )}$ & $213.0 \pm 24.1$ & $195.1 \pm 49.0$ \\
\hline & $7 \mathrm{~d}$ & $1540 \pm 101.9$ & $1671.4 \pm 103.0$ & $181.7 \pm 30.3$ & $200.0 \pm 46.0$ \\
\hline \multirow{3}{*}{$\begin{array}{l}\mathrm{CPu} \\
\text { (contra) }\end{array}$} & $6 \mathrm{hr}$ & $1681 \pm 72.9$ & $1577 \pm 158.6$ & $220.9 \pm 32.2$ & $212.0 \pm 37.1$ \\
\hline & $2 \mathrm{~d}$ & $1681 \pm 109.8$ & $1694 \pm 97.5$ & $205.6 \pm 31.3$ & $219.8 \pm 72.6$ \\
\hline & $7 \mathrm{~d}$ & $1542 \pm 104.8$ & $1704.8 \pm 75.4$ & $192.9 \pm 24.7$ & $229.9 \pm 59.2$ \\
\hline
\end{tabular}

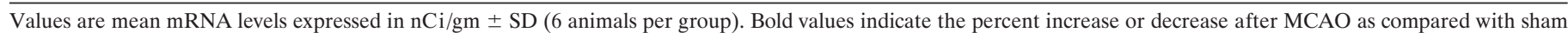

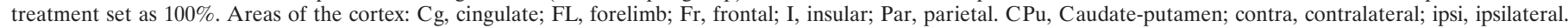
${ }^{*} p<0.05 ;{ }^{*} p<0.01$ versus the sham-operated group; Student's $t$ test.

mM dithiothreitol, $1 \times$ Denhardt's solution, $0.25 \mathrm{gm} / 1$ yeast tRNA, $10 \%$ dextran sulfate, and $50 \%$ formamide) to yield concentrations of 50,000 $\mathrm{dpm} / \mu \mathrm{l}(\mathrm{PPT}-\mathrm{A}, \mathrm{PPT}-\mathrm{B}, \mathrm{GAD}$, and PAG) or 100,000 dpm/ $\mathrm{\mu l}(\mathrm{NK} 1, \mathrm{NK} 2$, and NK3). After applying $50 \mu \mathrm{l}$ of hybridization solution, slides were coverslipped and incubated for $14 \mathrm{hr}$ at $60^{\circ} \mathrm{C}$. Coverslips were removed, and slides were washed in $2 \times$ SSC and $1 \times$ SSC for 20 min each followed by incubation in RNase buffer $(10 \mathrm{~mm}$ Tris, $\mathrm{pH} 8.0,0.5 \mathrm{M} \mathrm{NaCl}$, and $1 \mathrm{~mm}$ EDTA) containing $1 \mathrm{U} / \mathrm{ml}$ RNase T1 and $20 \mu \mathrm{g} / \mathrm{ml}$ RNase A (Boehringer Mannheim, Mannheim, Germany) for $30 \mathrm{~min}$ at $37^{\circ} \mathrm{C}$. The slides were washed at room temperature in $1 \times, 0.5 \times$, and $0.2 \times \mathrm{SSC}$ for 20 min each, at $60^{\circ} \mathrm{C}$ in $0.2 \times \mathrm{SSC}$ for $60 \mathrm{~min}$, and at room temperature in $0.2 \times \mathrm{SSC}$ and distilled water for 10 min each. The tissue was dehydrated in 50 and $70 \%$ 2-propanol. Slides were exposed together with ${ }^{14} \mathrm{C}$ standards (ARC, Inc., St. Louis, MO) to x-ray film for $6 \mathrm{hr}$ to $5 \mathrm{~d}$. For high-power bright- and dark-field microscopic analysis with the Olympus AX70 microscope, autoradiographic detection of ${ }^{35} \mathrm{~S}$ was performed with NTB-2 nuclear emulsion (Eastman Kodak, Rochester, NY). Exposure times were 10-42 d. Cresyl violet was used as a counterstain.

Double in situ hybridization histochemistry. Detection of two different RNA transcripts in the same tissue section was performed with radioactive- and nonradioactive-labeled probes as published previously with some modifications (Schafer and Day, 1995). Digoxigenin-labeled riboprobes for GAD and PPT-A were generated by in vitro transcription with a digoxigenin labeling mix containing $10 \mathrm{~mm}$ each of ATP, CTP, and GTP, $6.5 \mathrm{mM} \mathrm{UTP}$, and 3.5 mM digoxigenin-11-UTP (Boehringer Mannheim). After hydrolysis, probes were purified by sodium acetate precipitation and then added to the appropriate radioactive hybridization solution to a final concentration of $1 \mu \mathrm{g} / \mathrm{ml}$. Hybridization and washing procedures were performed as described above. For the detection of nonradioactive hybrids, slides were equilibrated to buffer1 (100 mM Tris and $150 \mathrm{~mm} \mathrm{NaCl,pH} \mathrm{7.5)} \mathrm{containing} 0.05 \%$ Tween 20 (Merck, Darmstadt, Germany). Blocking was performed by incubation for 1 $\mathrm{hr}$ in blocking buffer (buffer1 containing 2\% normal lamb serum). Alkaline phosphatase-conjugated anti-digoxigenin (anti-DIG) Fab fragments (Boehringer Mannheim) were diluted to $1 \mathrm{U} / \mathrm{ml}$ in blocking buffer. After the slides were rinsed with buffer1, the diluted antibody was applied for $1 \mathrm{hr}$ at room temperature. Excessive antibody was removed by two $15 \mathrm{~min}$ washes in buffer1. Slides were equilibrated to buffer $2(100 \mathrm{~mm}$ Tris, $100 \mathrm{~mm} \mathrm{NaCl}$, and $50 \mathrm{mM} \mathrm{MgCl} 2, \mathrm{pH} 9.4$ ) containing $0.05 \%$ Tween 20 before a $16 \mathrm{hr}$ color reaction in buffer 2 containing $0.2 \mathrm{~mm} 5$-bromo-4-chloro-3-indolyl phosphate and $0.2 \mathrm{~mm}$ nitroblue tetrazolium salt (Boehringer Mannheim). The reaction was stopped by washing the slides twice in double-distilled water. For detection of ${ }^{35} \mathrm{~S}$-labeled probes, slides were covered with $\mathrm{K} 5$ photoemulsion (Ilford) diluted 1:1 in water. Sections were exposed for 14-28 d before hybridization signals were detected.

Image analysis. Semiquantitative analysis of in situ hybridization autoradiograms was conducted as described (Schafer et al., 1993, 2000). From each animal in each group, film autoradiograms of three sections were digitized on an illumination screen by use of the MCID M4 image analysis system (MCID; Imaging Research, Inc., St. Catharines, Ontario, Canada). Densitometry was performed in five different manually selected areas: ipsilateral cingulate and frontal cortex, contralateral cingulate and frontal cortex, a contralateral area consisting of forelimb and parietal and insular cortex, and ipsilateral and contralateral dorsal caudate-putamen. For calibration, density measurements of the film background and the ${ }^{14} \mathrm{C}$ standards were obtained and plotted against the tissue radioactivity equivalents (nano-Curies per gram of tissue; ARC, Inc.). A threshold level was set to exclude pixel values below background density from the measurement. Measurements were expressed as integrated optical density (IOD; i.e., average optical density $\times$ proportional area). Mean values were determined for each brain region of each animal from the three sections analyzed.

The number of neurons expressing PPT or NK receptor mRNA per cerebrocortical area was determined in animals $2 \mathrm{~d}$ after MCAO and sham treatment. Three hybridized sections after autoradiography were digitized per animal under dark-field illumination with the Olympus AX70 microscope and the MCID image analysis system. After spatial calibration using a microscopic size standard, the number of positive neurons was counted in the size-determined ipsilateral and contralateral cingulate and frontal cortex and averaged from the three sections for each animal.

A sizewise measurement of ipsilateral and contralateral hemispheres in frozen coronal sections at bregma $0.7 \mathrm{~mm}$ was conducted in six animals at $6 \mathrm{hr}, 2 \mathrm{~d}$, and $7 \mathrm{~d}$ after sham operation or MCAO. One cresyl violet-stained coronal frozen section per animal was analyzed with the size-calibrated MCID image analysis system.

For analysis of proportional coexpression, 50 single- and double-labeled neurons after double in situ hybridization were counted in the ipsilateral cingulate and frontal cortex of two selected animals $2 \mathrm{~d}$ after MCAO and sham operation.

Statistical analysis. The mRNA levels and the number of counted PPT or NK receptor mRNA-expressing neurons per cortical area were compared between animals after MCAO $(n=6)$ and the stage-matched sham-operated animals $(n=6)$ by use of a nonpaired two-way Student's $t$ test. The size-determined areas of the ipsilateral and the contralateral hemispheres were compared with each other by use of a nonpaired two-way Student's $t$ test. Values of $p<0.05$ were considered statistically significant and labeled with one asterisk; $p$ values $<0.01$ were labeled with two asterisks.

\section{RESULTS}

\section{The MCAO-induced infarct pattern}

The ipsilateral infarction resulting $2 \mathrm{~d}$ after unilateral MCAO is illustrated in Figure 1. It extended from the cortical forelimb 


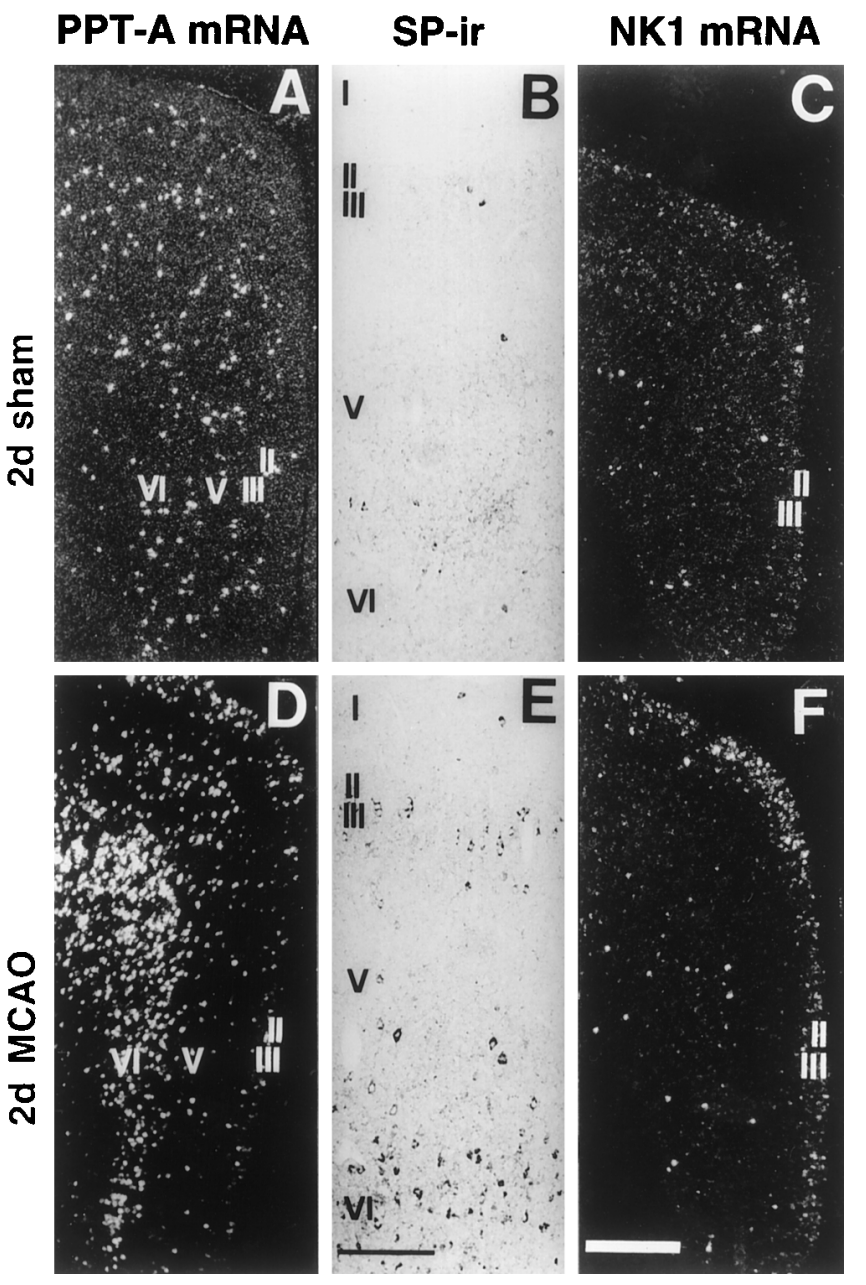

Figure 3. High-power dark- and bright-field micrographs of ipsilateral cingulate and frontal cortex demonstrating changes in the cellular localization and expression levels of PPT-A and NK1 mRNA and SP-like immunoreactivity (SP-ir) 2 d after MCAO. $A, D$, Note an increase in PPT-A mRNA levels per neuron and in the number of PPT-A mRNA-expressing neurons in laminae II-VI $(D)$ as compared with those in the sham animal $(A) . B, E$, There is a marked increase in the number of SP-immunoreactive neurons after MCAO $(E)$ as compared with that in the sham animal $(B) . C, F, \mathrm{NK} 1 \mathrm{mRNA}$ levels after MCAO are increased in laminae II-III $(F)$ as compared with that in the sham animal $(C)$. Cortical laminae are indicated by Roman numerals. Exposure times: $A, D, 9 \mathrm{~d} ; B, E$, no exposure; $C, F, 42 \mathrm{~d}$. Scale bars: $A, D, C, F, 500 \mu \mathrm{m} ; B, E, 150 \mu \mathrm{m}$.

area to the parietal and insular cortex, and in $\sim 30 \%$ of the animals, it also included the exterior part of the lateral caudate-putamen (Fig. 1). The ipsilateral cingulate and frontal cortex was not infarcted. In the rostrocaudal direction, the infarction was found to extend from bregma 3.7 to $-4.8 \mathrm{~mm}$. At $6 \mathrm{hr}$ and $2 \mathrm{~d}$ after MCAO, a swelling of the ipsilateral hemisphere was observed (Fig. 1). Measurement of the size of both hemispheres in frozen coronal sections at bregma $0.2 \mathrm{~mm}$ revealed an increase in the size of the ipsilateral hemisphere of $14.4 \%$ at $6 \mathrm{hr}$ and of $26 \%$ at $2 \mathrm{~d}$ after MCAO $(p<0.01)$ as compared with the size of the contralateral hemisphere. At $7 \mathrm{~d}$ after MCAO and in sham-operated animals at either time after surgery, significant differences in the sizes of the two hemispheres were not observed.

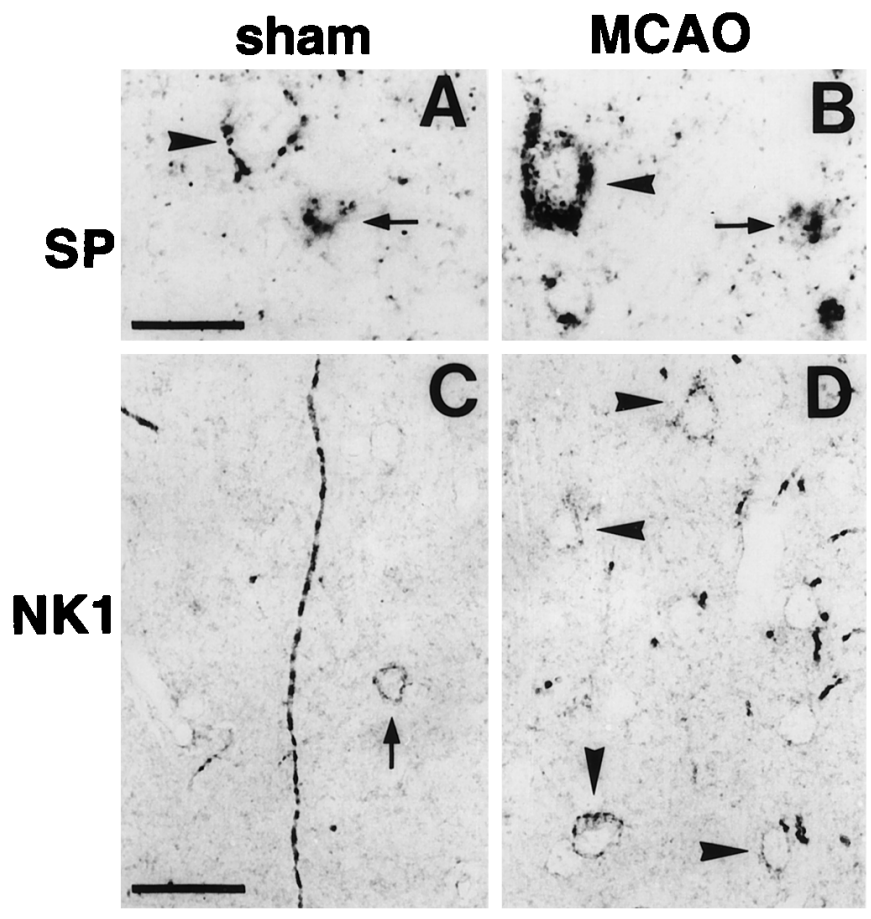

Figure 4. High-power immunocytochemistry for SP and NK1 receptor in the frontocingulate cortex at $2 \mathrm{~d}$ after sham treatment $(A, C)$ and $2 \mathrm{~d}$ after MCAO $(B, D)$. $A$, Absence of SP-ir from the perikaryon of a lamina $\mathrm{V}$ pyramidal neuron heavily invested by SP-like-immunoreactive terminals (arrowhead) and presence in a small nonpyramidal neuron (arrow). B, Presence of strong SP-ir in the perikaryon of a lamina V pyramidal neuron (arrowhead) and less strong SP-ir in the perikaryon of a small nonpyramidal neuron (arrow). Note the SP-like-immunoreactive terminals around a small SP-negative nonpyramidal neuron below the SPpositive pyramidal neuron. $C$, Presence of weak NK1-ir in a small nonpyramidal neuron (arrow) and in a trespassing fiber strand. $D$, Presence of moderately intense NK1-ir in several perikarya of pyramidal neurons of laminae II-III (arrowheads) and in some terminals. Scale bars, $25 \mu \mathrm{m}$.

\section{General pattern of MCAO-induced changes in PPT and NK receptor expression}

In addition to an early and sustained loss of neuronal expression of PPT-A, PPT-B, NK1, and NK3 in the infarct area itself, alterations in the neuronal expression of these genes occurred in distinct cerebral areas adjacent to the infarct. Non-neuronal NK1 expression was induced not only in the immediate vicinity to but also within the infarcted area itself. Statistically significant changes in PPT-A, NK1, and NK3 expression were exclusively seen on the hemisphere ipsilateral to the occlusion (see Figs. 2, 8; Tables 1, 2). PPT-B mRNA expression was altered in both hemispheres, although changes were much more pronounced ipsilateral than contralateral (see Fig. 8, Table 2). NK2 mRNA expression was not detectable in the brains of sham-operated animals or in brains of MCAO-treated animals at either time after surgery (data not shown).

\section{Transient changes in neuronal PPT-A, SP, and NK1 expression in noninfarcted ipsilateral frontal and cingulate cortex and caudate-putamen}

In situ hybridization revealed moderate levels of PPT-A mRNA and low levels of NK1 mRNA in the ipsilateral frontal and cingulate cortex at $6 \mathrm{hr}, 2 \mathrm{~d}$, and $7 \mathrm{~d}$ after sham operation as exemplarily shown at $2 \mathrm{~d}$ after sham operation (Fig. 2A,E). Quantitative image analysis revealed a dramatic increase both in PPT-A mRNA levels of 744\% $(p<0.05)$ and in NK1 mRNA 

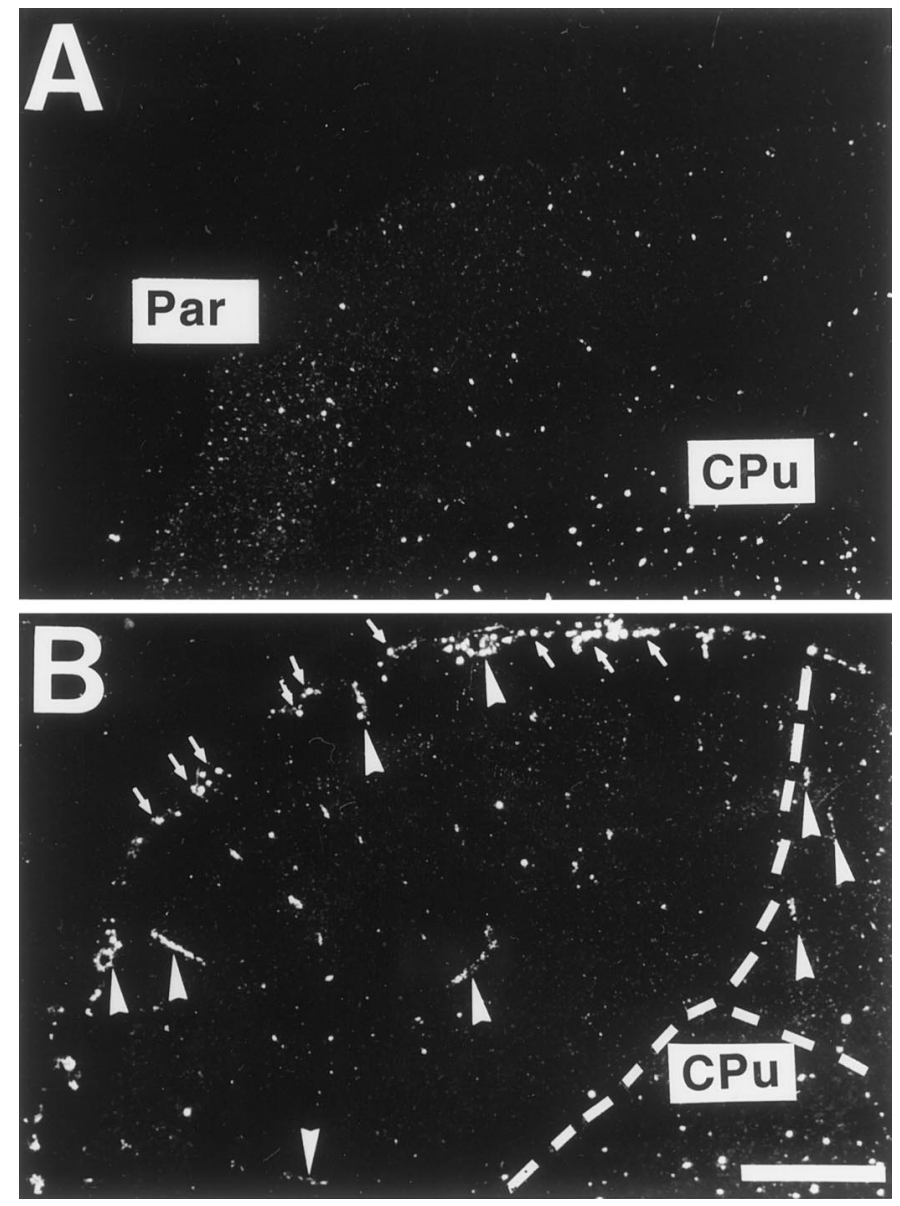

Figure 5. Comparision of NK1 expression in the parietal cortex (Par) of a rat $2 \mathrm{~d}$ after sham operation $(A)$ and a rat $2 \mathrm{~d}$ after MCAO $(B)$. Dark-field micrographs of coronal sections after in situ hybridization demonstrate the expression of NK1 mRNA in the leptomeninx at the circumference of the infarct $(B$, arrows) but not in the leptomeninx of a rat $2 \mathrm{~d}$ after sham operation $(A)$. Note the NK1 mRNA induction in vascular structures in the infarcted area and in juxtaposition to the infarct ( $B$, arrowheads). The dotted line marks the border of the infarcted area. Exposure time, $42 \mathrm{~d}$. Scale bar, $1 \mathrm{~mm}$. $\mathrm{CPu}$, Caudate-putamen.

levels of $376 \%(p<0.05)$ in this region at $2 \mathrm{~d}$ after MCAO as compared with $2 \mathrm{~d}$ after sham operation (Fig. 2A,C,E, G; Table 1). At $6 \mathrm{hr}$ and at $7 \mathrm{~d}$, no differences in PPT-A and NK1 mRNA levels between sham- and MCAO-treated animals were seen (Fig. $2 A, B, D-F, H$; Table 1$)$.

Dark- and bright-field analysis demonstrated that PPT-A mRNA-expressing neurons and SP-like-immunoreactive neurons located in the frontocingular cortical laminae II-VI were more numerous in animals $2 \mathrm{~d}$ after MCAO than in animals $2 \mathrm{~d}$ after sham operation (Fig. $3 A, B, D, E$ ). The number of PPT-A mRNAcontaining neurons in a given cortical area was increased by $207 \%$ $(p<0.05)$. After sham operation, SP-like immunostaining was restricted to nonpyramidal neurons (Fig. 4A). SP-likeimmunoreactive terminals were observed perisomatic to nonpyramidal and pyramidal neurons (Fig. 4). At $2 \mathrm{~d}$ after MCAO, however, SP-like immunoreactivity (SP-ir) was additionally induced in the perikarya of a subpopulation of pyramidal cells in laminae II-III (data not shown) and lamina V (Fig. 4B). Thus, MCAO most likely caused de novo expression of PPT-A mRNA and SP in a subset of pyramidal cerebrocortical neurons in addition to an apparent upregulation of PPT-A mRNA and SP ex-
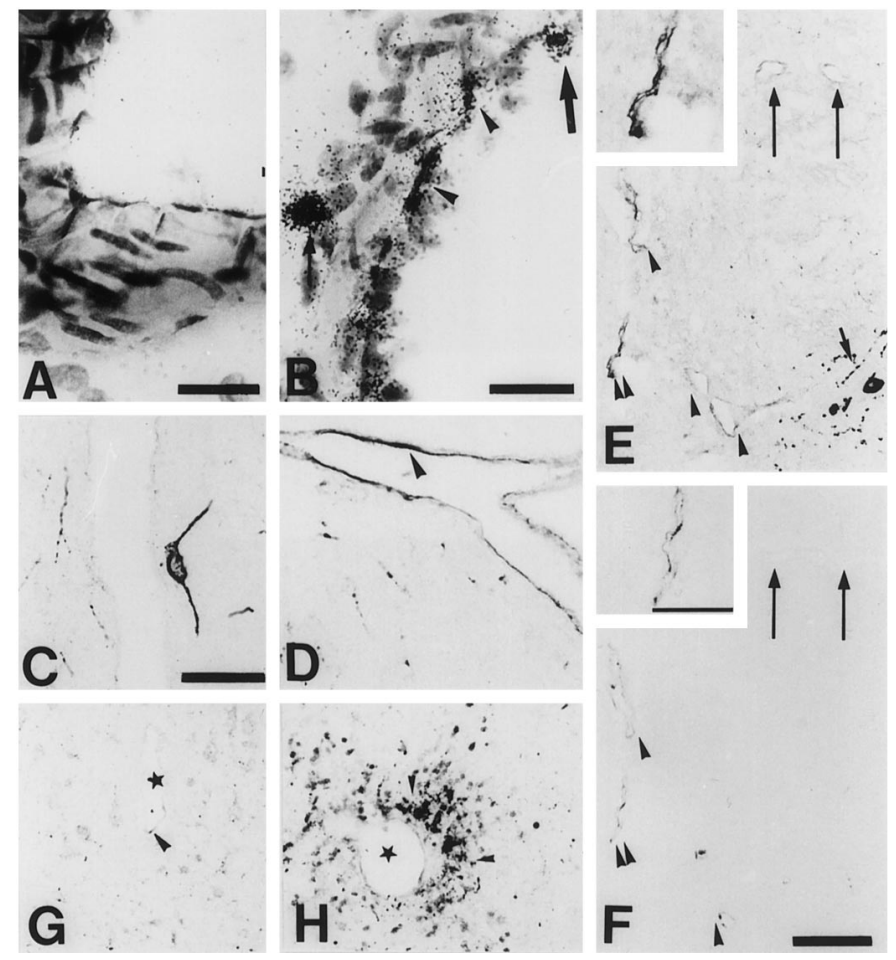

Figure 6. High-power in situ hybridization and immunohistochemical analysis of the cellular localization of NK1 expression in the parietal cortex $2 \mathrm{~d}$ after MCAO as compared with sham operation. B, After MCAO, NK1 mRNA is present in endothelial cells (arrowheads), in an intraluminal leukocyte (bold arrow) adhering to the endothelium, and in a paravascular cell (arrow) of a blood vessel in the leptomeninx covering the infarcted area. $A$, In contrast, note the absence of any NK1 mRNA hybridization signal related to the wall of a meningeal blood vessel of a sham-operated rat. $D$, NK1-ir is strongly induced in the endothelium (arrowhead) of a meningeal blood vessel that extends into lamina I of the noninfarcted cortex immediately adjacent to the infarcted cortex and is also present in some varicose fibers. $C$, In a sham-operated rat, NK1-ir is absent from the endothelium of a meningeal blood vessel extending into lamina II of the parietal cortex, whereas a paravascular neuron and a trespassing varicose fiber are NK1 immunopositive. $E, F$, Adjacent sections alternately immunostained for $\mathrm{NK} 1(E)$ and CD62-P, a marker of activated venular endothelium $(F)$, reveal the presence of NK1 in the endothelium of most CD62-P-positive cerebral venules (single arrowheads). One double-labeled venule (double arrowheads) is shown at high power as an inset in $E$ and $F$. Small blood vessels immunonegative for both $\mathrm{NK} 1$ and CD62-P are marked by long arrows $(E, F)$. The short arrow in $E$ marks NK1-ir related to neurons and fibers in the adjacent noninfarcted caudate-putamen. $H$, At $2 \mathrm{~d}$ after MCAO, note the accumulation of SP-like-immunoreactive fibers and terminals (arrowheads) in the perivascular space of a small blood vessel (asterisk) located in the infarcted cortex. $G$, At $2 \mathrm{~d}$ after sham treatment, note the absence of SP-likeimmunoreactive fibers from the perivascular space (arrowhead) of a cortical blood vessel (asterisk). Exposure times: $A, B, 42 \mathrm{~d}$. Scale bars: $A$, $D, 33.3 \mu \mathrm{m} ; B, 20 \mu \mathrm{m} ; C, E-H, 100 \mu \mathrm{m}$; insets, $E, F, 50 \mu \mathrm{m}$.

pression in neurons with constitutive synthesis of SP (Fig. 3). A constitutive expression of SP in pyramidal neurons below the detection levels, however, cannot be excluded.

Dark-field analysis showed that NK1 mRNA expression increased in cortical laminae II-III rather than in the deeper cortical laminae (Fig. 3C,F). The number of NK1 mRNApositive neurons per area was elevated by $127 \%(p<0.05)$ at $2 \mathrm{~d}$ after MCAO as compared with $2 \mathrm{~d}$ after sham operation. Highresolution immunocytochemistry revealed an induction of NK1 receptor protein in neurons with pyramidal shape (Fig. $4 D$ ) at $2 \mathrm{~d}$ after MCAO, whereas in sham-operated rats NK1-ir was confined 

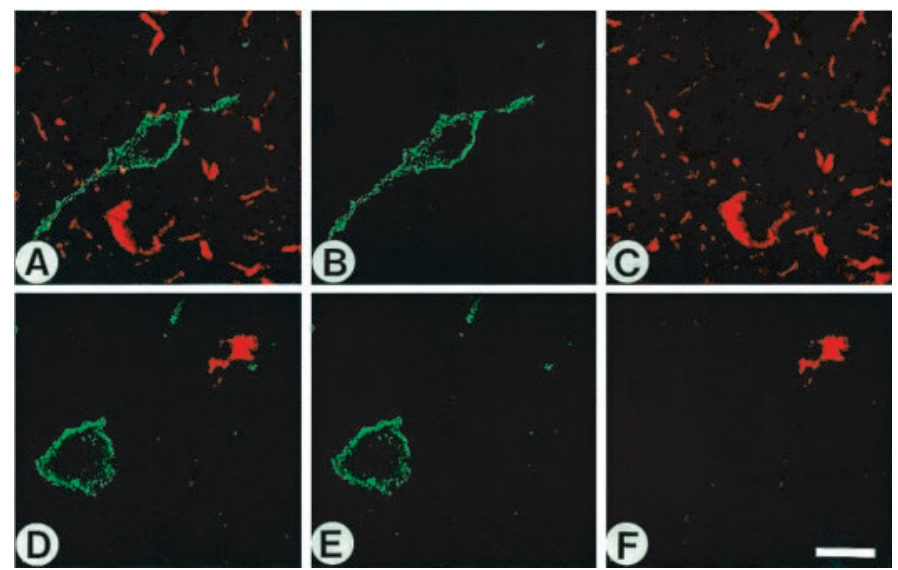

Figure 7. Absence of NK1-ir from activated astrocytes and microglial cells. False-color micrographs are shown of confocal images from double immunofluorescence for NK1 (green; $A, B, D, E$ ) and GFAP (red; $A, C$ ) and $C 1 \mathrm{q}(\mathrm{red} ; D, F)$ in the frontal cortex ipsilateral to the lesion $2 \mathrm{~d}$ after MCAO. NK1-like-immunoreactive neurons $(A, B, D, E)$ exhibit a strong somatodendritic labeling; the heavy cytosolic NK1-ir is evidence of NK1 internalization. GFAP-like-immunoreactive profiles $(A, C)$ of activated astrocytes and C1q-like-immunoreactive profiles $(D, F)$ of an activated microglial cell are clearly distinct from NK1-like immunolabeling. Scale bar, $20 \mu \mathrm{m}$.

to nonpyramidal neurons, presumably interneurons (Fig. 4C). NK1-ir was not altered at early (6 hr) and later (7 d) stages after MCAO (data not shown). Thus, the expression of NK1 and its ligand SP was transiently induced by MCAO in subsets of cortical pyramidal cells, in which a constitutive expression of SP and NK1 was undetectable. In the pyramidal cell type, the induction of NK1 expression was confined to laminae II-III, whereas SP expression was also induced in lamina $\mathrm{V}$.

Besides a complete loss of neuronal PPT-A and NK1 mRNA expression in the variably infarcted part of the ipsilateral caudateputamen, quantitative image analysis of x-ray autoradiograms revealed that PPT-A mRNA expression increased in the noninfarcted ipsilateral caudate-putamen by $18 \%(p<0.05)$ at $6 \mathrm{hr}$ after MCAO and decreased by 38\% $(p<0.01)$ at $2 \mathrm{~d}$ after MCAO but did not change $7 \mathrm{~d}$ after MCAO as compared with stage-matched sham-operated groups (Fig. $2 A-D$, Table 1). In contrast to PPT-A, the expression of NK1 mRNA in the noninfarcted caudate-putamen was not affected by MCAO (Fig. $2 E-H$, Table 1). At $6 \mathrm{hr}$ after MCAO a small increase in PPT-A mRNA appeared to occur in the contralateral putamen of some animals (Fig. 2B), but densitometry revealed no statistically significant differences in PPT-A mRNA levels between contralateral caudate-putamen and sham (Table 1).

\section{Induction of NK1 expression in non-neuronal cells of the infarcted hemisphere}

Although NK1 expression was not detectable in non-neuronal cells at any stage after sham operation, MCAO caused an induction of NK1 expression in the infarcted area and in the adjacent cortical and subcortical areas, especially at 2 d (Fig. 5). Furthermore, NK1 was induced in the leptomeninx covering the infarct (Fig. 5). High-resolution analysis in bright-field illumination revealed that NK1 hybridization signals were induced in endothelial cells, in intraluminal leukocytes adhering to the endothelium, and in paravascular cells at $2 \mathrm{~d}$ after MCAO (Fig. 6A,B). The endothelial induction of NK1 expression at $2 \mathrm{~d}$ after MCAO was also observed with NK1 immunocytochemistry (Fig. 6C,D).

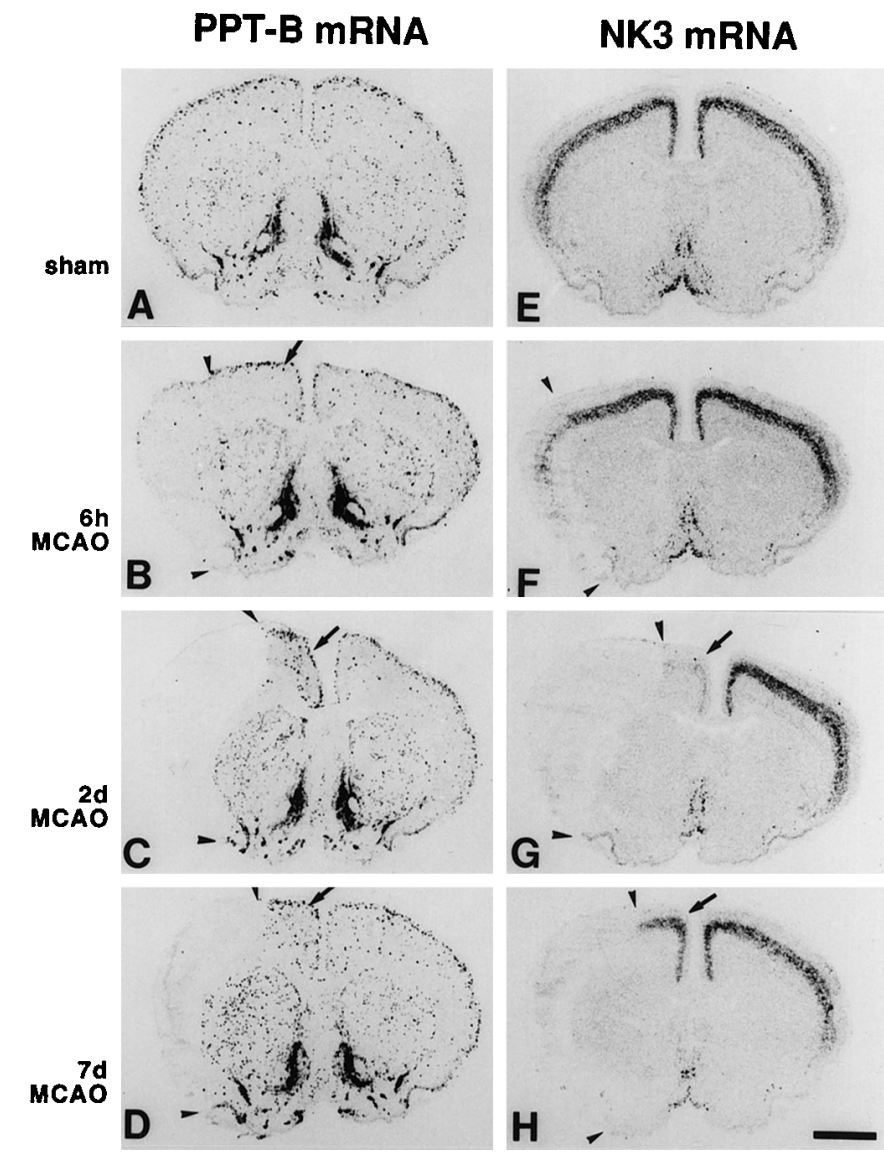

Figure 8. Spatiotemporal patterns of changes in cerebral PPT-B and NK3 mRNA expression after MCAO. Low-power micrographs of x-ray autoradiograms after in situ hybridization of coronal sections through the forebrain are shown. For identification of brain areas see nomenclature in Figure 1. The lateral borders of the infarcted area at each stage after MCAO are marked by arrowheads. Note that PPT-B and NK3 mRNAs become completely depleted from the infarcted area $(B-D, F-H) . A-D$, PPT-B mRNA levels in the noninfarcted ipsilateral cingulate and frontal cortex $(B-D$, arrows) are increased $2 \mathrm{~d}(C)$ and $7 \mathrm{~d}(D)$ after MCAO as compared with the levels in an animal $2 \mathrm{~d}$ after sham operation $(A)$. In the ipsilateral caudate-putamen, PPT-B mRNA levels are increased at 2 and $7 \mathrm{~d}$ after MCAO $(C, D)$ as compared with the levels in the sham-treated animal $(A) . E-H$, Note the dramatic decrease in NK3 mRNA levels in the ipsilateral cingulate and frontal cortex $2 \mathrm{~d}$ after MCAO $(G$, arrow) as compared with the levels in an animal $2 \mathrm{~d}$ after sham operation $(E)$ (for high magnification see Fig. $9 F)$. At $7 \mathrm{~d}$ after MCAO $(H)$, NK3 mRNA levels appear only marginally decreased in the ipsilateral cingulate and frontal cortex (H,arrow) as compared with the levels in the sham-operated animal $(E)$. Sham-operated animals $2 \mathrm{~d}$ after surgery $(A, E)$ are representative of sham animals $6 \mathrm{hr}$ and $7 \mathrm{~d}$ after surgery (data not shown). Exposure times: $A-D, 36 \mathrm{hr} ; E-H, 48 \mathrm{hr}$. Scale bar, $2.5 \mathrm{~mm}$.

Costaining for NK1 and CD62-P, a recently established marker of endothelial activation in cerebral venules (Suzuki et al., 1998), suggests that NK1 is specifically induced in activated cerebrovascular venules (Fig. 6E,F). The induction of NK1 expression in endothelial cells at $2 \mathrm{~d}$ after MCAO was shown to be transient. Neither NK1 mRNA nor NK1-ir was seen in endothelial cells at $7 \mathrm{~d}$ after MCAO. The NK1 mRNA expression in the leptomeninx at $7 \mathrm{~d}$ after MCAO (as demonstrated in Fig. $2 \mathrm{H}$ at low power) was found to be mainly associated with paravascular cells and intraluminal leukocytes but rarely with endothelial cells (data not shown). In the perivascular space of some blood vessels located at the border to the infarct, an accumulation of SP-like- 
Table 2. Influence of MCAO on PPT-B and NK3 mRNA levels in cerebral cortex and caudate-putamen

\begin{tabular}{|c|c|c|c|c|c|}
\hline & & \multicolumn{2}{|l|}{ PРT-B } & \multicolumn{2}{|l|}{$\mathrm{NK} 3$} \\
\hline & & Sham & MCAO & Sham & MCAO \\
\hline \multirow{3}{*}{$\begin{array}{l}\mathrm{Cg}, \mathrm{Fr} \\
\text { (ipsi) }\end{array}$} & $6 \mathrm{hr}$ & $56.7 \pm 12.9$ & $53.6 \pm 12.1$ & $110.8 \pm 21.7$ & $106.4 \pm 9.6$ \\
\hline & $2 \mathrm{~d}$ & $48.6 \pm 11.7$ & $139.7 \pm 68.7^{*}(+\mathbf{1 8 7 \%})$ & $121.3 \pm 15.4$ & $18.3 \pm 21.2^{* *}(-84 \%)$ \\
\hline & $7 \mathrm{~d}$ & $43.7 \pm 6.1$ & $107.0 \pm 40.3^{*}(+\mathbf{1 4 4 \%})$ & $89.1 \pm 17.6$ & $63.0 \pm 14.0^{*}(-29 \%)$ \\
\hline \multirow{3}{*}{$\begin{array}{l}\mathrm{Cg}, \mathrm{Fr} \\
\text { (contra) }\end{array}$} & $6 \mathrm{hr}$ & $48.6 \pm 16.4$ & $47.4 \pm 12.2$ & $106.7 \pm 15.2$ & $101.5 \pm 15.9$ \\
\hline & $2 \mathrm{~d}$ & $44.0 \pm 12.6$ & $65.3 \pm 31.1$ & $104.4 \pm 13.1$ & $102.7 \pm 21.8$ \\
\hline & $7 \mathrm{~d}$ & $52.9 \pm 10.3$ & $53.9 \pm 22.0$ & $83.5 \pm 12.6$ & $70.3 \pm 12.3$ \\
\hline \multirow{3}{*}{$\begin{array}{l}\text { FL, Par, I } \\
\text { (contra) }\end{array}$} & $6 \mathrm{hr}$ & $54.5 \pm 16.0$ & $56.3 \pm 18.1$ & $95.6 \pm 24.5$ & $79.7 \pm 13.3$ \\
\hline & $2 \mathrm{~d}$ & $48.8 \pm 12.5$ & $76.3 \pm 23.3^{*}(+56 \%)$ & $86.1 \pm 17.2$ & $105.1 \pm 24.9$ \\
\hline & $7 \mathrm{~d}$ & $65.7 \pm 22.4$ & $69.5 \pm 26.6$ & $66.6 \pm 11.7$ & $61.4 \pm 11.4$ \\
\hline \multirow{3}{*}{$\begin{array}{l}\mathrm{CPu} \\
\text { (ipsi) }\end{array}$} & $6 \mathrm{hr}$ & $22.4 \pm 2.1$ & $12.5 \pm 3.3^{* *}(-44 \%)$ & n.d. & n.d. \\
\hline & $2 \mathrm{~d}$ & $22.0 \pm 4.1$ & $53.5 \pm 11.0^{* *}(+\mathbf{1 4 3 \%})$ & n.d. & n.d. \\
\hline & $7 \mathrm{~d}$ & $19.2 \pm 7.1$ & $51.1 \pm 19.7^{* *}(+\mathbf{1 6 6 \%})$ & n.d. & n.d. \\
\hline \multirow{3}{*}{$\begin{array}{l}\mathrm{CPu} \\
\text { (contra) }\end{array}$} & $6 \mathrm{hr}$ & $22.5 \pm 3.6$ & $22.3 \pm 5.8$ & n.d. & n.d. \\
\hline & $2 \mathrm{~d}$ & $23.9 \pm 3.0$ & $32.4 \pm 4.3^{*}(+\mathbf{3 5} \%)$ & n.d. & n.d. \\
\hline & $7 \mathrm{~d}$ & $25.5 \pm 7.3$ & $24.8 \pm 9.9$ & n.d. & n.d. \\
\hline
\end{tabular}

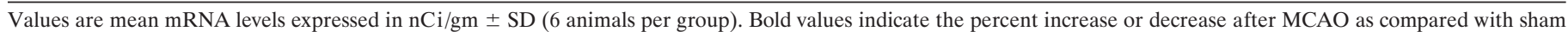

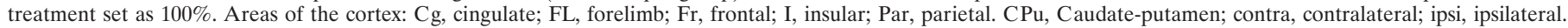
${ }^{*} p<0.05 ;{ }^{*} p<0.01$ versus the sham-operated group; Student's $t$ test.

immunoreactive fibers was detected (Fig. 6G,H). Such perivascular accumulations of SP-ir were not seen either in sham-operated animals or in unlesioned cerebral parenchyma of rats subjected to MCAO.

To determine whether NK1 expression occurs in astrocytes and microglial cells, which are known to be activated by cerebral ischemia (Culmsee et al., 1999; Schafer et al., 2000), we used double fluorescence confocal microscopy for NK1 as well as for the astrocyte and microglial markers GFAP and C1q, respectively. It was revealed that NK1 expression was absent from activated astrocytes and microglia at any stage after focal ischemia (Fig. 7). Correspondingly, high-resolution in situ hybridization did not provide any evidence of an expression of NK1 in glial cells (data not shown).

\section{Changes in PPT-B and NK3 expression in neurons of the noninfarcted ipsilateral frontal and cingulate cortex and caudate-putamen}

Changes in cerebrocortical PPT-B and NK3 expression ipsilateral to the ischemia-induced lesion exhibited an opposite pattern with a sustained increase in PPT-B expression and a robust decrease in $\mathrm{NK} 3$ expression at $2 \mathrm{~d}$ and a trend toward recovery in NK3 expression at $7 \mathrm{~d}$. In situ hybridization and quantitative image analysis revealed that PPT-B mRNA levels in the ipsilateral cingulate and frontal cortex increased by $187 \%(p<0.05)$ at $2 \mathrm{~d}$ and remained increased by $144 \%(p<0.05)$ at $7 \mathrm{~d}$ after MCAO as compared with the stage-matched sham-operated groups (Fig. 8 , Table 2). In contrast, NK3 mRNA levels decreased by $84 \%$ $(p<0.01)$ at $2 \mathrm{~d}$ and by $29 \%(p<0.05)$ at $7 \mathrm{~d}$ as compared with stage-matched sham-operated animals (Fig. 8, Table 2). Neither PPT-B mRNA nor NK3 mRNA levels were changed at $6 \mathrm{hr}$ after MCAO (Fig. 8B). Dark-field analysis of the frontocingulate cortex $2 \mathrm{~d}$ after MCAO revealed that the increases in PPT-B mRNA expression occurred in neurons of laminae II-III and VI (Fig. 9). The number of PPT-B mRNA-expressing neurons per area increased by $46.7 \%(p<0.05)$. Correspondingly, immunocytochemistry demonstrated that the number of neurons staining for the protein precursor to $\mathrm{NKB}$ in laminae II-III and VI was increased (Fig. 9B,E). Furthermore, immunocytochemical analysis at high magnification revealed enhanced intensity of the NKBlike immunoreactivity (NKB-ir) at 2 and $7 \mathrm{~d}$ after MCAO as compared with sham treatment (data not shown). The number of NK3 mRNA-expressing neurons, which were predominantly localized in lamina V (Fig. 9), was decreased by $37.1 \%(p<0.05)$ at $2 \mathrm{~d}$ after MCAO as compared with $2 \mathrm{~d}$ after sham operation (Table 2).

Although NK3 mRNA expression was not changed in the cortex contralateral to MCAO, PPT-B mRNA expression in the contralateral forelimb, parietal, and insular areas of the cortex (i.e., in the areas that correspond to the infarct on the ipsilateral side, see Fig. 1) was increased by $56 \%(p<0.05)$ at $2 \mathrm{~d}$ after MCAO as compared with stage-matched sham-operated rats (Table 2). In contrast, the contralateral areas of the cingulate and frontal cortex that correspond to the noninfarcted cingulate and frontal areas on the ipsilateral side exhibited no differences in PPT-B mRNA levels between sham-treated and MCAO-treated animals (Table 2).

Besides a complete loss of PPT-B mRNA expression in the infarcted part of the ipsilateral caudate-putamen, quantitative image analysis of $\mathrm{x}$-ray autoradiograms revealed a decrease in PPT-B mRNA levels of $44 \%$ at $6 \mathrm{hr}(p<0.01)$ and increases of $143 \%$ $(p<0.01)$ and 166\% $(p<0.01)$ at 2 and $7 \mathrm{~d}$ after MCAO, respectively, as compared with stage-matched sham-operated rats (Fig. 8, Table 2). In the contralateral caudate-putamen, a minor increase $(35 \% ; p<0.05)$ in the expression of PPT-B mRNA was measured at $2 \mathrm{~d}$ after MCAO as compared with the respective sham-operated group (Table 2). NK3 mRNA was not detected in the caudate-putamen in any of the six experimental groups (Fig. $8 E-H$, Table 2).

\section{Changes in PPT and NK receptor mRNA expression in relation to each other and to GABAergic and glutamatergic phenotypes}

To identify MCAO-induced changes of PPT-A, PPT-B, NK1, and NK3 expression in relation to each other and to GABAergic or glutamatergic phenotypes and to test the hypothesis that phenotype shifts may be involved, double in situ hybridizations 

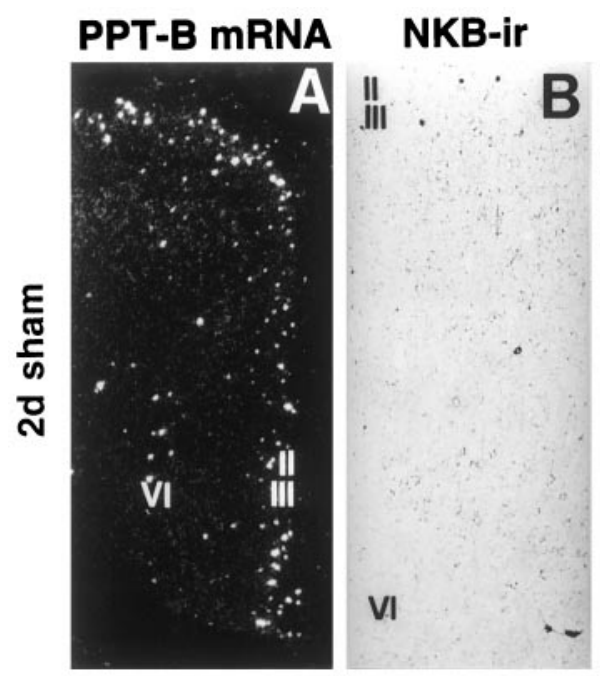

\section{NK3 mRNA}

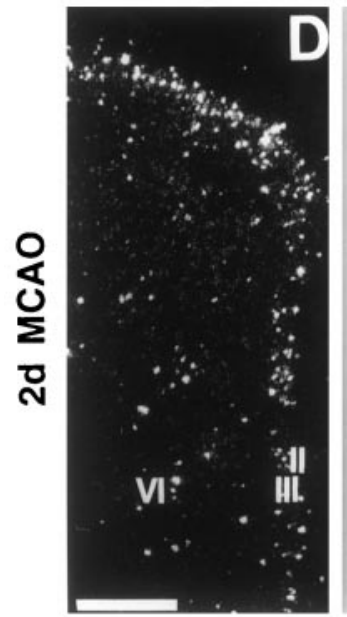

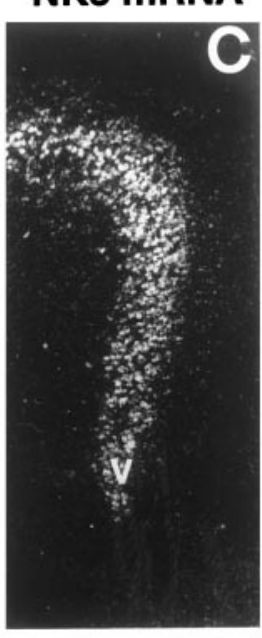

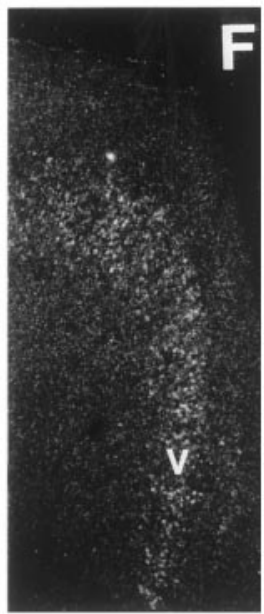

Figure 9. High-power dark- and bright-field micrographs of ipsilateral cingulate and frontal cortex demonstrating cellular localization and changes in the expression levels of PPT-B mRNA $(A, D)$, NKB-ir $(B, E)$, and NK3 mRNA $(C, F) 2 \mathrm{~d}$ after MCAO as compared with the levels after a sham operation. $A, D$, After MCAO, there is a marked increase in PPT-B mRNA levels per neuron $(D)$ and a small increase in the number of PPT-B mRNA-expressing neurons in laminae II-III and VI $(D)$ as compared with those in a sham animal $(A) . B, E$, Note the increase in the levels of NKB-ir per cell and the small increase in neurons showing NKB-ir in laminae II-III and VI after MCAO $(E)$ as compared with the sham operation $(B) . C, F$, There is a dramatic reduction of NK3 mRNA levels in virtually all NK3 mRNA-expressing neurons in lamina $\mathrm{V}$ after MCAO $(F)$ as compared with the sham operation $(C)$. Cortical laminae are indicated by Roman numerals. Exposure times: $A, D, 16 \mathrm{~d} ; C, F, 21 \mathrm{~d}$. Scale bars: $A, C, D, F, 500 \mu \mathrm{m} ; B, E, 150 \mu \mathrm{m}$.

with radioactive or DIG-labeled riboprobes were performed. GABAergic neurons were identified by the expression of the mRNA of their established marker enzyme GAD. Expression of PAG was used to identify glutamatergic cerebrocortical neurons (Najlerahim et al., 1990; Kaneko and Mizuno, 1994). The analysis was limited to the frontocingulate cortex and the experimental group $2 \mathrm{~d}$ after MCAO when changes in PPT and NK receptor expression were found to be most pronounced (Tables 1, 2).

Upregulation of PPT-A expression in GABAergic neurons and induction of PPT-A expression in glutamatergic pyramidal neurons

In sham-operated rats, PPT-A mRNA expression was found to be confined essentially to GAD mRNA-positive neurons (Fig.
$10 A, B)$. Cell counts of double- and single-labeled neurons revealed that 49 neurons out of 50 PPT-A-positive neurons (98\%) expressed GAD mRNA. In contrast, at $2 \mathrm{~d}$ after MCAO only 21 of 50 PPT-A mRNA-containing neurons were counted to express GAD mRNA. However, PPT-A mRNA levels in GAD mRNApositive neurons were higher after MCAO than after sham operation (Fig. 10A,F). Because there was no reduction in the number of GAD mRNA-expressing neurons per cortical area at $2 \mathrm{~d}$ after MCAO (data not shown), we conclude that the MCAO-induced PPT-A mRNA expression in GAD-negative neurons may reflect de novo expression of PPT-A mRNA in non-GABAergic neurons. MCAO caused an induction of PPT-A mRNA in large neurons of laminae II-III and V exhibiting high levels of PAG mRNA (Fig. 10H). In rats subjected to 2 d MCAO, $56 \%$ of PPT-A mRNA-expressing neurons were counted to coexpress PAG mRNA, whereas in sham-operated animals, coexistence of PPT-A in neurons expressing PAG mRNA was seen only very rarely. In conjunction with our observation that MCAO induced SP immunostaining in pyramidal neurons (Fig. 4B), this indicates that the induction of a PPT-A phenotype in GAD mRNAnegative neurons occurred in a substantial subpopulation of glutamatergic pyramidal neurons.

\section{Upregulation of NK1 expression in GABAergic neurons and} induction in non-GABAergic neurons

In sham-operated rats, NK1 mRNA expression was confined to a subpopulation of GAD mRNA-positive neurons (Fig. 10D). After MCAO, NK1 mRNA expression was upregulated in GABAergic neurons, and an additional expression of NK1 mRNA in GAD mRNA-negative neurons was detectable (Fig. 10I). After MCAO, 52\% of the NK1 mRNA-expressing neurons were counted to be GAD mRNA negative.

\section{Induction of coexpression of NK1 and PPT-A}

In sham-treated rats, NK1 and PPT-A mRNAs were expressed in different neurons (Fig. 10E). Out of those neurons in a given cortical area that were positive for either PPT-A mRNA or NK1 mRNA or both, we counted a proportion of $2 \%$ of these neurons coexpressing NK1 and PPT-A mRNAs, 60\% expressing PPT-A mRNA, and $38 \%$ expressing NK1 mRNA. In contrast, MCAO caused dramatic coexpression of NK1 and PPT-A mRNAs in a major subpopulation of neurons (Fig. 10J). At $2 \mathrm{~d}$ after MCAO, neuronal proportions in laminae II-III consisted of $23 \%$ of the neurons with coexpression for PPT-A and NK1 mRNA, 47\% for PPT-A, and 30\% for NK1.

\section{Restriction of upregulation of PPT-B and downregulation of} $N K 3$ to GABAergic and non-GABAergic neurons, respectively In sham-operated rats, PPT-B expression was confined to GAD mRNA-containing neurons (Fig. 11A). After MCAO, the expression of PPT-B mRNA was increased but remained restricted to GAD mRNA-expressing neurons (Fig. 11D). After MCAO, NK3 mRNA levels were decreased in GAD mRNA-negative neurons (Fig. $11 F$ ) but remained confined to GAD mRNA-negative neurons as in sham-operated rats (Fig. 11C).

\section{Persistence of segregated expression of PPT- $A$ and PPT-B}

The observed upregulation of PPT-A and PPT-B mRNA expression (Tables 1,2) occurred in different neuronal subsets (Fig. $11 E$ ). Thus, the strict segregation of PPT-A and PPT-B mRNA expression seen in sham-treated rats (Fig. $11 B$ ) was conserved after MCAO. However, we found that MCAO shifted the ratio of PPT-A- over PPT-B-positive neurons from 1.3 after sham treat- 


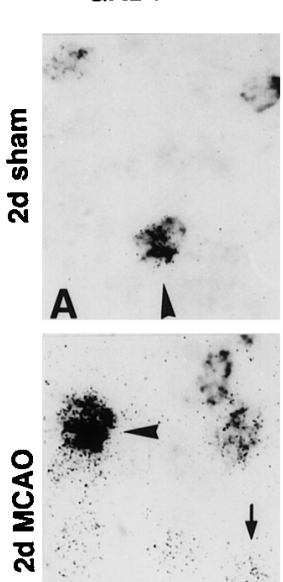

$\mathbf{F}$
${ }^{D I G P P T-A+}{ }^{355}$ GAD

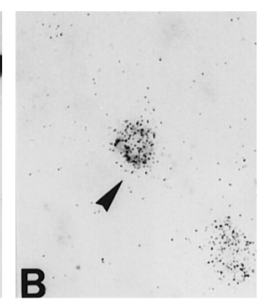

B

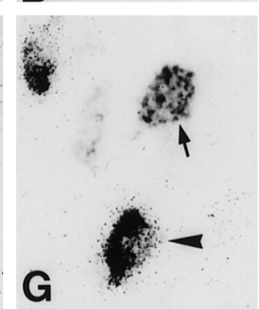

${ }^{\text {DIGPPT-A+ }}{ }^{355}$ PAG

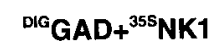

${ }^{\text {DIGPPT-A }+{ }^{355} \text { NK1 }}$
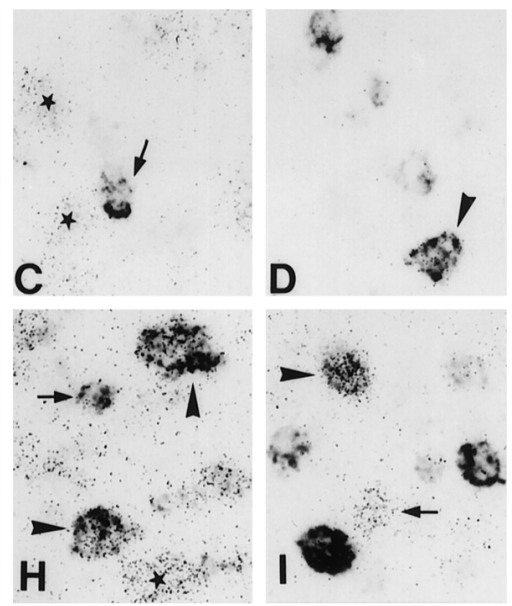

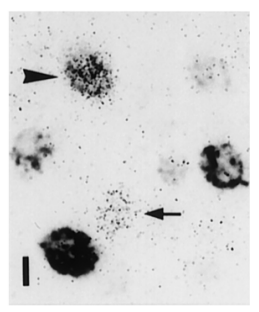

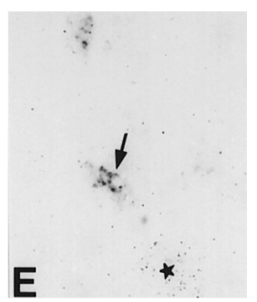

E

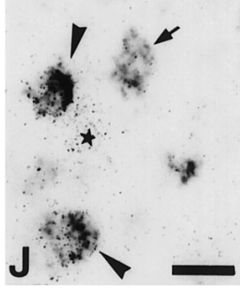

Figure 10. High-resolution double in situ hybridization analysis of the influence of MCAO on PPT-A and NK1 mRNA cophenotypes in cerebrocortical neurons by the use of ${ }^{35} \mathrm{~S}$ - and digoxigenin-labeled riboprobes. Digoxigenin labeling $(D I G)$ is recognized as a black reaction product, and ${ }^{35} \mathrm{~S}$ labeling $(35 S)$ is seen as grains. $A, B, F, G$, After both sham operation $(A, B)$ and MCAO $(F, G)$, PPT-A mRNA and GAD mRNA coexist in a neuronal subpopulation (arrowheads). After MCAO, PPT-A mRNA is induced in a subpopulation of GAD mRNA-negative neurons $(F, G$, arrows). $C, H$, In a sham-operated rat, PPT-A mRNA is present in a PAG mRNA-negative neuron $(C$, arrow) but not in PAG mRNA-positive neurons $(C$, asterisks). After MCAO, PPT-A mRNA is induced in a PAG mRNA-positive neuron $(H$, arrowheads) in addition to being expressed in a PAG mRNA-negative neuron (H, arrow). PAG mRNA-positive neurons that are PPT-A mRNA negative are labeled by an asterisk in $H$. $D$, I, In a sham-operated animal, NK1 mRNA expression is restricted to a subpopulation of GAD mRNA-positive neurons ( $D$, arrowhead). After MCAO, NK1 mRNA is induced in a GAD mRNA-negative neuron ( $I$, arrow) and is also expressed in a GAD mRNA-positive neuron ( $I$, arrowhead). E, $J$, In a sham-operated animal, NK1 mRNA is confined to a PPT-A mRNA-negative neuron (E, asterisk). After MCAO $(J)$, NK1 mRNA is induced in PPT-A mRNA-positive neurons $(J$, arrowheads); in addition NK1 mRNA is present in a PPT mRNA-negative neuron (J, asterisk). Note the PPT-A mRNA-positive neurons with no signal for NK1 mRNA (E, J, arrows). Exposure times: $A-C, F-H, 14 \mathrm{~d} ; D, E, I, J, 21 \mathrm{~d}$. Scale bar, $25 \mu \mathrm{m}$.

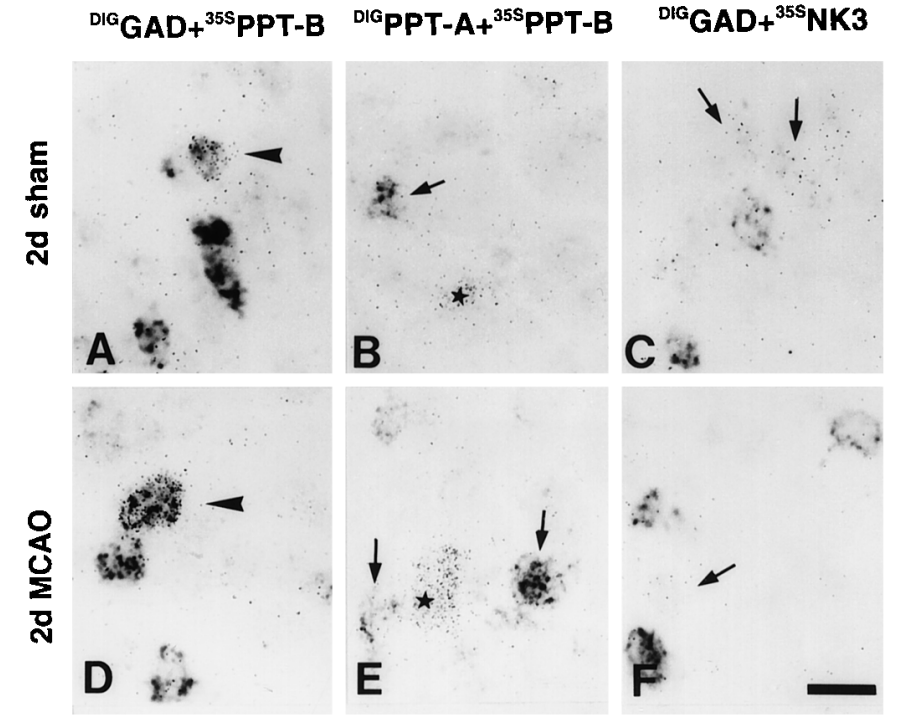

Figure 11. High-resolution double in situ hybridization analysis of the influence of MCAO on PPT-B and NK3 mRNA cophenotypes in cerebrocortical neurons by the use of ${ }^{35} \mathrm{~S}(35 S)$ - and digoxigenin $(D I G)$ labeled riboprobes. $A, D$, After both sham operation $(A)$ and MCAO $(D)$, PPT-B mRNA is confined to a subpopulation of GAD mRNA-positive neurons (arrowheads). B, E, PPT-A (arrows) and PPT-B (asterisks) mRNA expression occurs in different neuronal populations, both after sham treatment and after MCAO. $C, F, \mathrm{NK} 3 \mathrm{mRNA}$ expression occurs in GAD mRNA-negative neurons of a sham-operated rat (C, arrows). After MCAO, NK3 mRNA is decreased in a GAD mRNA-negative neuron $(F$, arrow). Exposure time, $14 \mathrm{~d}$. Scale bar, $25 \mu \mathrm{m}$.

ment to 2.8 after MCAO, suggesting that the MCAO-induced increase in PPT-A-expressing neurons was much stronger than that of PPT-B-expressing neurons.

\section{DISCUSSION}

We provide three main findings in the ischemic rat brain. We demonstrate, first, major plasticity of preprotachykinin (PPT-A and PPT-B) and tachykinin receptor (NK1, NK3, but not NK2) gene expression; second, substantial proportional shifts in the expression of these genes in relation to GABAergic or glutamatergic neurons; and third, ischemia-induced expression of NK1 in activated cerebrovenular endothelium but no NK1 expression in activated microglia or astroglia. This is the first report on cellspecific regulation of tachykinin and tachykinin receptor genes after MCAO or other models of stroke. Furthermore, we expand the knowledge on the constitutive expression patterns of the tachykinin system in the rat brain.

\section{Constitutive tachykinin and tachykinin receptor expression in the cerebral cortex}

A scattered expression of PPT-A, PPT-B, and NK1 and a predominant localization of NK3 mRNA in neurons of lamina $\mathrm{V}$ were observed in agreement with previous studies in control rats (Warden and Young, 1988; Maeno et al., 1993; Whitty et al., 1995; Shughrue et al., 1996). In addition, we demonstrate that PPT-A and PPT-B mRNAs are expressed in separate populations of GABAergic neurons of the cerebral cortex, which most likely constitute local circuit interneurons. This is in concordance with a recent immunocytochemical report showing coexistence of the GABAergic marker GAD with PPT-A and PPT-B and segregation of PPT-A and PPT-B immunoreactivity in cerebrocortical neurons (Kaneko et al., 1998). Our finding that NK1 mRNA expression was restricted to GABAergic neurons conforms to double immunofluorescence demonstrating coexistence of GAD and NK1 (Kaneko et al., 1994). We provide novel evidence that NK1 and PPT-A mRNA-expressing neurons represent separate populations of GABAergic neurons; only a very minor population 

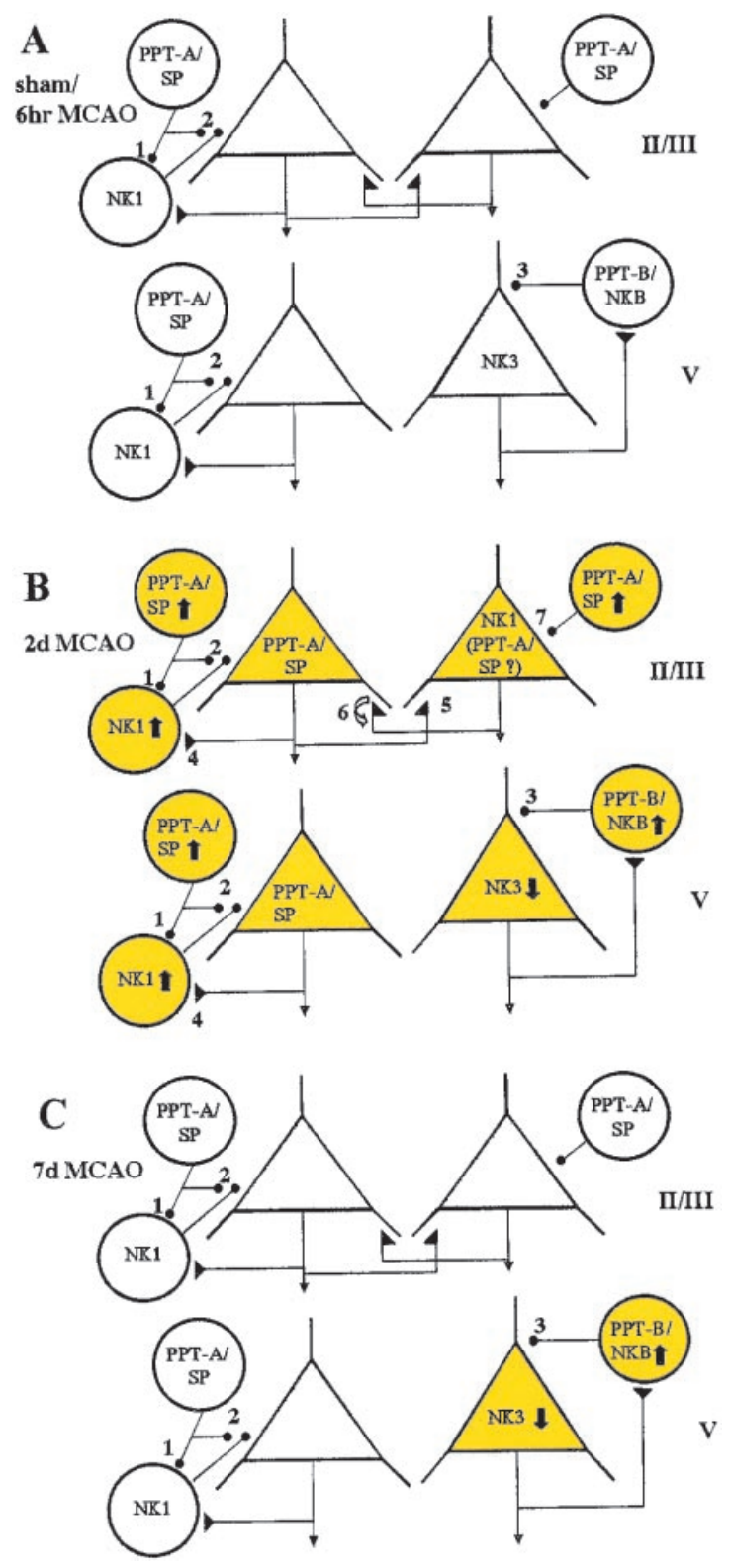

Figure 12. Schematic diagrams summarizing presumed cerebrocortical tachykininergic circuits and their ischemia-induced alterations in relation to inhibitory GABAergic and excitatory glutamatergic pathways. GABAergic interneurons and glutamatergic pyramidal cells are depicted as large circles and triangles, respectively. Inhibitory and excitatory terminals are symbolized as small filled circles and triangles, respectively. Cortical laminae are symbolized by Roman numerals. Symbols and principles of cortical circuits were adopted from Somogyi et al. (1998). A, Tachykininergic circuits at the early stage $(6 \mathrm{hr})$ after focal ischemia that are not altered and correspond to control conditions. SP synthesis is restricted to NK1-negative GABAergic interneurons. SPergic/GABAergic interneurons project to non-SPergic/GABAergic interneurons and pyramidal cells $(1,2)$. SP released from these GABAergic interneurons is likely to act on somatodendritic NK1 receptors (1) and, hypothetically, on NK1 receptors presynaptic (2) to pyramidal cells. This may result in increased release of GABA and, thus, facilitation of GABAergic inhibition of pyramidal neurons. NKB is synthesized in SP-negative GABAergic interneurons, and NK3 is synthesized in pyramidal cells of lamina V. NKB is proposed to be an excitatory cotransmitter in local GABAergic circuits with synaptic input to NK3-expressing pyramidal cells (3). B, Tachykininergic circuit alterations at $2 \mathrm{~d}$ after ischemia and their functional implications. $\mathrm{SP}$ expression is increased in GABAergic interneurons. Enhanced neurotransmission of SP at their projection sites $(1+2)$ may result in a reinforcement of the presumed NK1-mediated facilitation of GABAergic of neurons coexpresses NK1 and PPT-A mRNA. By demonstrating NK3 mRNA in non-GABAergic lamina $\mathrm{V}$ neurons, we lend support to the immunohistochemical finding that NK3 is constitutively expressed in pyramidal (glutamatergic) neurons of the deep cerebral cortex (Ding et al., 1996).

\section{Stage-specific changes in tachykinin and tachykinin receptor expression and possible functional implications for GABAergic and glutamatergic neurotransmission in the exofocal neocortex}

The absence of differences in tachykinin and tachykinin receptor expression in the exofocal cortex at $6 \mathrm{hr}$ after MCAO indicates that cortical tachykininergic circuits and functions in the early stage of focal ischemia are essentially similar to those under nonischemic conditions (Fig. 12A). In contrast, fundamental changes in tachykinin and $\mathrm{NK}$ receptor expression occur $2 \mathrm{~d}$ after MCAO (Fig. 12B). The transient upregulation in neuronal PPT-A and NK1 expression $2 \mathrm{~d}$ after MCAO suggests enhanced neurotransmission of $\mathrm{SP}$ at the NK1 receptor with two possible consequences. First, the NK1-mediated activation of the GABAergic inhibitory input to excitatory pyramidal cells (Maubach et al., 1998) is enhanced. This may represent a mechanism of autoprotection from ischemia-induced cerebrocortical hyperexcitability (Fig. 12B). Second, the ischemia-induced expression of NK1 in pyramidal neurons recruits a circuit in which SP can facilitate hyperexcitability of glutamatergic neurons via NK1 (Fig. 12B). NK1 activation enhances NMDA receptormediated neuronal firing in hippocampal and spinal cord neurons (Urban et al., 1994; Heppenstall and Fleetwood, 1997; Lieberman and Mody, 1998). PPT-A-deficient mice exhibit reduced excitotoxicity-induced neuronal apoptosis (Liu et al., 1999). Furthermore, an NK1 receptor antagonist reduces the infarct size after focal cerebral ischemia (Yu et al., 1997).

Because NKB and the NK3 agonist senktide cause acceleration of extracellularly recorded spontaneous discharges in lamina V neurons of rat brain slices (Maubach et al., 1998), we suggest that the increase of NKB in the exofocal cortex most likely results in NK3-mediated hyperexcitability of glutamatergic lamina $\mathrm{V}$ neurons, where NK3 is expressed constitutively (Ding et al.,

\section{$\leftarrow$}

inhibition of pyramidal neurons. The increased synthesis of NK1 in GABAergic interneurons may compensate for presumed NK1 receptor desensitization. SP is de novo synthesized in pyramidal cells of laminae II-V, and NK1 synthesis is induced in pyramidal cells of laminae II-III with a possible NK1 and SP coinduction. Thus, SP released as an excitatory cotransmitter from glutamatergic pyramidal neurons may have dual functions, both to contribute to the activation of the GABAergic inhibitory pathway (4) and to stimulate the glutamatergic excitatory pathway via activation of pyramidal NK1 heteroreceptors (5) or autoreceptors (6). Furthermore, the de novo-expressed NK1 receptors of pyramidal glutamatergic neurons are likely targets of SP released from GABAergic interneurons (7). NKB synthesis in SP-negative GABAergic interneurons is enhanced and possibly paralleled by increased NKB release at NK3-positive pyramidal cells (3). This is presumed to add to the activation of the glutamatergic excitatory pathway. $C$, Tachykininergic circuitry alterations and partial normalizations at $7 \mathrm{~d}$ after ischemia. Increases in SP and NK1 expression seen at $2 \mathrm{~d}$ in both GABAergic and glutamatergic pathways are no longer present $(A)$. In contrast, the synthesis of NKB in GABAergic interneurons remains increased at approximately the same level seen after $2 \mathrm{~d}$. The decrease of NK3 seen in pyramidal neurons at $2 \mathrm{~d}$ is almost normalized to levels seen in controls. Thus, functional alterations at $7 \mathrm{~d}$ after ischemia are limited to the $\mathrm{NKB} / \mathrm{NK} 3$-mediated influence on excitatory glutamatergic neurotransmission of pyramidal neurons. 
1996) and downregulated after ischemia (this study), possibly reflecting receptor desensitization.

Plasticity of the tachykinin system in cerebrocortical circuits might contribute to poststroke seizures, which occur in a substantial population of stroke patients (Rumbach et al., 2000). The minor increase in the expression of PPT-B mRNA in the cerebrocortical area contralateral to the infarct may result in enhanced contralateral release of $\mathrm{NKB}$ and contribute to the recently reported hyperexcitability in the cortex contralateral to focal ischemia (Reinecke et al., 1999). However, neuroprotective actions of NKB are also conceivable (Wenk et al., 1997).

\section{Possible implications of ischemia-induced alterations of PPT-A and PPT-B expression in the caudate-putamen}

The stage-specific ischemia-induced changes in PPT-A and PPT-B expression in the noninfarcted part of the caudateputamen with very minor contralateral changes are most likely caused by the influence of altered corticostriatal input. Corticostriatal afferents influence striatal PPT-A mRNA levels (Somers and Beckstead, 1990), possibly by activation of metabotropic glutamate receptors (Wang and McGinty, 1998). SP has been proposed to be released in the rat striatum after strong glutamatergic stimulation and to control NMDA-evoked release of ACh by activation of NK1 receptors on cholinergic striatal interneurons (Blanchet et al., 1998). The ischemia-induced late increase in striatal PPT-B expression may result in the alteration of dopamine neurotransmission because nigrostriatal dopaminergic neurons are endowed with $\mathrm{NK} 3$ receptors and excited by the NK3 agonist senktide (Marco et al., 1998). Thus, dopaminergic and cholinergic neurotransmission in subcortical pathways of the extrapyramidal motor system may be affected by the ischemiainduced plasticity of PPT-A and PPT-B expression in the striatum.

\section{Evidence of a role of endothelial NK1 receptors in the neuroinflammatory pathophysiology of cerebral ischemia}

Our study is the first to report an induction of NK1 receptor in activated venular endothelium of the ischemic brain, suggesting that endothelial receptors for SP may serve a similar pathophysiological mechanism in the brain as in the periphery. SP acting on endothelial NK1 receptors plays an important role in peripheral inflammatory reactions and diseases by enhancing venular permeability and leukocyte diapedesis via interactions with proinflammatory cytokines and endothelial cell adhesion molecules (Weihe et al., 1991; Shepheard et al., 1993; Bowden et al., 1994; Nakagawa et al., 1995; Maggi, 1997; Saban et al., 1997; Quinlan et al., 1999a,b). Cerebrovenular endothelial cells have been suggested to bind SP after interleukin-1 administration in vitro (Cioni et al., 1998). The synthesis of interleukin-1 in brain microglial cells and paravascular macrophages is increased after cerebral ischemia (Davies et al., 1999). Thus, interleukin-1 may contribute to the ischemia-induced increase of endothelial NK1. The strong induction of endothelial NK1 expression at $2 \mathrm{~d}$ after MCAO coincides with the reported evidence of major cerebral protein extravasation, edema, and infiltration of inflammatory cells at 2 d after MCAO (Belayev et al., 1996). Therefore, we suggest that the induction of NK1 receptor in cerebrovenular endothelium contributes to impairment of the blood-brain barrier $(\mathrm{BBB})$ in the ischemic brain with a likely involvement of intercellular adhesion molecule-1 (ICAM-1) and other endothelial cell adhesion molecules (Nakagawa et al., 1995). ICAM-1 expression is upregulated in the endothelial BBB in the early phases of cerebral ischemia (Wang et al., 1994), and ICAMdeficient mice exhibit reduced leukocyte invasion and brain lesions (Connolly et al., 1996). The infarct-reducing effect of an NK1 antagonist (Yu et al., 1997) may be in part caused by reduced endothelium-dependent edema and leukocyte infiltration. Our finding that cells adhering to the luminal endothelium and some paravascular cells express NK1 mRNA suggests that inflammatory cells bearing NK1 receptors that have yet to be identified may play a role in the neuroinflammatory reaction to brain ischemia. Our observation of a sustained increase of NK1 expression in meningeal blood vessels in close vicinity to and within the infarct indicates that NK1 may be involved in the control of postischemic blood flow by trigeminovascular afferents as suggested previously (Macfarlane et al., 1991) or in angiogenesis because angiogenic properties of NK1 and SP have been proposed (Baluk et al., 1997).

\section{No evidence of constitutive or ischemia-induced NK1 receptor expression in glia}

The absence of NK1 expression from quiescent glial cells in control animals as well as from reactive astroglia and microglia in the penumbral region as demonstrated in this study indicates that NK1 receptors do not play a direct role in glial activation after ischemic brain injury. In contrast, an induction of binding sites for $\mathrm{SP}$ in astrocytes after lesion of rabbit optic nerve has been demonstrated (Mantyh et al., 1989), and NK1 mRNA expression has been found in cultured astrocytes (Too et al., 1994). This indicates that the potential of astrocytes to express NK1 may depend on the species, the type of lesion, and the astrocyte subtype. Astrocyte NK1 expression in vivo may be fundamentally different from that in vitro.

\section{Conclusions}

We have revealed differential adaptive plasticity of the tachykinin system in distinct inhibitory and excitatory cerebrocortical circuits after MCAO. We propose that the ischemia-induced increase of SP and NK1 expression in GABAergic neurons enhances GABAergic inhibitory circuits that may result in endogenous neuroprotection against hyperexcitation. In contrast, the MCAO-induced expression of NK1 in glutamatergic pyramidal cells in conjunction with increased local availability of SP may aggravate glutamate-mediated hyperexcitability and neurotoxicity. Enhanced NKBergic neurotransmission at pyramidal cells expressing NK3 may specifically contribute to cerebrocortical hyperexcitability during late stages of ischemic injury. The induction of $\mathrm{NK} 1$ in the endothelial BBB is likely to contribute to edema and leukocyte diapedesis and is regarded as a neuroinflammatory component in stroke pathophysiology. Thus, specific tachykinin receptors may be promising drug targets in ischemic cerebrovascular diseases.

\section{REFERENCES}

Angerer LM, Cox KH, Angerer RC (1987) Demonstration of tissuespecific gene expression by in situ hybridization. Methods Enzymol 152:649-661.

Baluk P, Bowden JJ, Lefevre PM, McDonald DM (1997) Upregulation of substance $P$ receptors in angiogenesis associated with chronic airway inflammation in rats. Am J Physiol 273:L565-L571.

Belayev L, Busto R, Zhao W, Ginsberg MD (1996) Quantitative evaluation of blood-brain barrier permeability following middle cerebral artery occlusion in rats. Brain Res 739:88-96.

Blanchet F, Gauchy C, Perez S, Soubrie P, Glowinski J, Kemel ML (1998) Distinct modifications by neurokinin1 (SR140333) and neurokinin2 (SR48968) tachykinin receptor antagonists of the $N$-methyl-D- 
aspartate-evoked release of acetylcholine in striosomes and matrix of the rat striatum. Neuroscience 85:1025-1036.

Bonner TI, Affolter HU, Young AC, Young WD (1987) A cDNA encoding the precursor of the rat neuropeptide, neurokinin B. Brain Res 388:243-249.

Bowden JJ, Garland AM, Baluk P, Lefevre P, Grady EF, Vigna SR, Bunnett NW, McDonald DM (1994) Direct observation of substance P-induced internalization of neurokinin 1 (NK1) receptors at sites of inflammation. Proc Natl Acad Sci USA 91:8964-8968.

Carter MS, Krause JE (1990) Structure, expression, and some regulatory mechanisms of the rat preprotachykinin gene encoding substance $\mathrm{P}$, neurokinin $\mathrm{A}$, neuropeptide $\mathrm{K}$, and neuropeptide gamma. J Neurosci 10:2203-2214.

Cioni C, Renzi D, Calabro A, Annunziata P (1998) Enhanced secretion of substance P by cytokine-stimulated rat brain endothelium cultures. J Neuroimmunol 84:76-85.

Connolly EJ, Winfree CJ, Springer TA, Naka Y, Liao H, Yan SD, Stern DM, Solomon RA, Gutierrez RJ, Pinsky DJ (1996) Cerebral protection in homozygous null ICAM-1 mice after middle cerebral artery occlusion. Role of neutrophil adhesion in the pathogenesis of stroke. J Clin Invest 97:209-216.

Culmsee C, Stumm RK, Schafer MK, Weihe E, Krieglstein J (1999) Clenbuterol induces growth factor mRNA, activates astrocytes, and protects rat brain tissue against ischemic damage. Eur J Pharmacol 379:33-45.

Davies CA, Loddick SA, Toulmond S, Stroemer RP, Hunt J, Rothwell NJ (1999) The progression and topographic distribution of interleukin1beta expression after permanent middle cerebral artery occlusion in the rat. J Cereb Blood Flow Metab 19:87-98.

del Zoppo G, Ginis I, Hallenbeck JM, Iadecola C, Wang X, Feuerstein GZ (2000) Inflammation and stroke: putative role for cytokines, adhesion molecules and iNOS in brain response to ischemia. Brain Pathol 10:95-112.

Dietzschold B, Schwaeble W, Schafer MK, Hooper DC, Zehng YM, Petry F, Sheng H, Fink T, Loos M, Koprowski H, Weihe E (1995) Expression of $\mathrm{C} 1 \mathrm{q}$, a subcomponent of the rat complement system, is dramatically enhanced in brains of rats with either Borna disease or experimental allergic encephalomyelitis. J Neurol Sci 130:11-16.

Ding YQ, Shigemoto R, Takada M, Ohishi H, Nakanishi S, Mizuno N (1996) Localization of the neuromedin K receptor (NK3) in the central nervous system of the rat. J Comp Neurol 364:290-310.

Dirnagl U, Iadecola C, Moskowitz MA (1999) Pathobiology of ischaemic stroke: an integrated view. Trends Neurosci 22:391-397.

Di Sebastiano P, Fink T, di Mola FF, Weihe E, Innocenti P, Friess H, Buchler MW (1999) Neuroimmune appendicitis. Lancet 354:461-466.

Heppenstall PA, Fleetwood WS (1997) The glycine site of the NMDA receptor contributes to neurokinin1 receptor agonist facilitation of NMDA receptor agonist-evoked activity in rat dorsal horn neurons. Brain Res 744:235-245.

Hershey AD, Dykema PE, Krause JE (1991) Organization, structure, and expression of the gene encoding the rat substance $\mathrm{P}$ receptor. J Biol Chem 266:4366-4374.

Holzer P (1998) Neurogenic vasodilatation and plasma leakage in the skin. Gen Pharmacol 30:5-11.

Hurd YL, Keller E, Sotonyi P, Sedvall G (1999) Preprotachykinin-A mRNA expression in the human and monkey brain: an in situ hybridization study. J Comp Neurol 411:56-72.

Kaneko T, Mizuno N (1994) Glutamate-synthesizing enzymes in GABAergic neurons of the neocortex: a double immunofluorescence study in the rat. Neuroscience 61:839-849.

Kaneko T, Shigemoto R, Nakanishi S, Mizuno N (1994) Morphological and chemical characteristics of substance $\mathrm{P}$ receptor-immunoreactive neurons in the rat neocortex. Neuroscience 60:199-211.

Kaneko T, Murashima M, Lee T, Mizuno N (1998) Characterization of neocortical non-pyramidal neurons expressing preprotachykinins $\mathrm{A}$ and B: a double immunofluorescence study in the rat. Neuroscience 86:765-781.

Kennedy PG, Rodgers J, Jennings FW, Murray M, Leeman SE, Burke JM (1997) A substance P antagonist, RP-67,580, ameliorates a mouse meningoencephalitic response to Trypanosoma brucei brucei. Proc Natl Acad Sci USA 94:4167-4170.

Lee JM, Zipfel GJ, Choi DW (1999) The changing landscape of ischaemic brain injury mechanisms. Nature 399:A7-A14.

Lieberman DN, Mody I (1998) Substance P enhances NMDA channel function in hippocampal dentate gyrus granule cells. J Neurophysiol $80: 113-119$.

Liu H, Cao Y, Basbaum AI, Mazarati AM, Sankar R, Wasterlain CG (1999) Resistance to excitotoxin-induced seizures and neuronal death in mice lacking the preprotachykinin A gene. Proc Natl Acad Sci USA 96:12096-12101

Ljungdahl A, Hokfelt T, Nilsson G (1978) Distribution of substance P-like immunoreactivity in the central nervous system of the rat. I. Cell bodies and nerve terminals. Neuroscience 3:861-943.

Lucas LR, Hurley DL, Krause JE, Harlan RE (1992) Localization of the tachykinin neurokinin B precursor peptide in rat brain by immunocytochemistry and in situ hybridization. Neuroscience 51:317-345.

Macfarlane R, Tasdemiroglu E, Moskowitz MA, Uemura Y, Wei EP, Kontos HA (1991) Chronic trigeminal ganglionectomy or topical capsaicin application to pial vessels attenuates postocclusive cortical hyperemia but does not influence postischemic hypoperfusion. J Cereb Blood Flow Metab 11:261-271.

Maeno H, Kiyama H, Tohyama M (1993) Distribution of the substance $\mathrm{P}$ receptor (NK-1 receptor) in the central nervous system. Brain Res Mol Brain Res 18:43-58.

Maggi CA (1997) The effects of tachykinins on inflammatory and immune cells. Regul Pept 70:75-90.

Mantyh PW, Johnson DJ, Boehmer CG, Catton MD, Vinters HV, Maggio JE, Too HP, Vigna SR (1989) Substance P receptor binding sites are expressed by glia in vivo after neuronal injury. Proc Natl Acad Sci USA 86:5193-5197.

Marchand JE, Sant GR, Kream RM (1998) Increased expression of substance $\mathrm{P}$ receptor-encoding $\mathrm{mRNA}$ in bladder biopsies from patients with interstitial cystitis. Br J Urol 81:224-228.

Marco N, Thirion A, Mons G, Bougault I, Le FG, Soubrie P, Steinberg R (1998) Activation of dopaminergic and cholinergic neurotransmission by tachykinin NK3 receptor stimulation: an in vivo microdialysis approach in guinea pig. Neuropeptides 32:481-488.

Marksteiner J, Wahler R, Bellmann R, Ortler M, Krause JE, Sperk G (1992) Limbic seizures cause pronounced changes in the expression of neurokinin B in the hippocampus of the rat. Neuroscience 49:383-395.

Maubach KA, Cody C, Jones RS (1998) Tachykinins may modify spontaneous epileptiform activity in the rat entorhinal cortex in vitro by activating GABAergic inhibition. Neuroscience 83:1047-1062.

Melton DA, Krieg PA, Rebagliati MR, Maniatis T, Zinn K, Green MR (1984) Efficient in vitro synthesis of biologically active RNA and RNA hybridization probes from plasmids containing a bacteriophage SP6 promoter. Nucleic Acids Res 12:7035-7056.

Mileusnic D, Lee JM, Magnuson DJ, Hejna MJ, Krause JE, Lorens JB, Lorens SA (1999) Neurokinin-3 receptor distribution in rat and human brain: an immunohistochemical study. Neuroscience $89: 1269-1290$

Najlerahim A, Harrison PJ, Barton AJ, Heffernan J, Pearson RC (1990) Distribution of messenger RNAs encoding the enzymes glutaminase, aspartate aminotransferase and glutamic acid decarboxylase in rat brain. Brain Res Mol Brain Res 7:317-333.

Nakagawa N, Sano H, Iwamoto I (1995) Substance P induces the expression of intercellular adhesion molecule-1 on vascular endothelial cells and enhances neutrophil transendothelial migration. Peptides $16: 721-725$

Nakaya Y, Kaneko T, Shigemoto R, Nakanishi S, Mizuno N (1994) Immunohistochemical localization of substance $\mathrm{P}$ receptor in the central nervous system of the adult rat. J Comp Neurol 347:249-274.

Quinlan KL, Song IS, Naik SM, Letran EL, Olerud JE, Bunnett NW, Armstrong CA, Caughman SW, Ansel JC (1999a) VCAM-1 expression on human dermal microvascular endothelial cells is directly and specifically up-regulated by substance P. J Immunol 162:1656-1661.

Quinlan KL, Naik SM, Cannon G, Armstrong CA, Bunnett NW, Ansel JC, Caughman SW (1999b) Substance P activates coincident NF-ATand NF-kappa B-dependent adhesion molecule gene expression in microvascular endothelial cells through intracellular calcium mobilization. J Immunol 163:5656-5665.

Reinecke S, Lutzenburg M, Hagemann G, Bruehl C, Neumann HT, Witte OW (1999) Electrophysiological transcortical diaschisis after middle cerebral artery occlusion (MCAO) in rats. Neurosci Lett 261:85-88.

Roder C, Bellmann R, McCarson KE, Krause JE, Sperk G (1994) Kainic acid induced seizures cause a marked increase in the expression of neurokinin-3 receptor mRNA in the rat cerebellum. Neurosci Lett $181: 158-160$

Rohrenbeck AM, Bette M, Hooper DC, Nyberg F, Eiden LE, Dietzschold $\mathrm{B}$, Weihe E (1999) Upregulation of COX-2 and CGRP expression in resident cells of the Borna disease virus-infected brain is dependent upon inflammation. Neurobiol Dis 6:15-34.

Rumbach L, Sablot D, Berger E, Tatu L, Vuillier F, Moulin T (2000) Status epilepticus in stroke: report on a hospital-based stroke cohort. Neurology 54:350-354.

Saban MR, Saban R, Bjorling D, Haak FM (1997) Involvement of leukotrienes, TNF-alpha, and the LFA-1/ICAM-1 interaction in substance P-induced granulocyte infiltration. J Leukoc Biol 61:445-451.

Sasai Y, Nakanishi S (1989) Molecular characterization of rat substance $\mathrm{K}$ receptor and its mRNAs. Biochem Biophys Res Commun 165:695-702.

Schafer MK, Day R (1995) In situ hybridization techniques to map processing enzymes. In: Methods in neurosciences, Vol 23, Peptidases and neuropeptide processing (Smith AI, ed), pp 16-44. San Diego: Academic.

Schafer MK, Nohr D, Krause JE, Weihe E (1993) Inflammationinduced upregulation of NK1 receptor mRNA in dorsal horn neurones. NeuroReport 4:1007-1010.

Schafer MK, Schwaeble WJ, Post C, Salvati P, Calabresi M, Sim RB, 
Petry F, Loos M, Weihe E (2000) Complement C1q is dramatically upregulated in brain microglia in response to transient global cerebral ischemia. J Immunol 164:5446-5452.

Schwaeble W, Schafer MK, Petry F, Fink T, Knebel D, Weihe E, Loos M (1995) Follicular dendritic cells, interdigitating cells, and cells of the monocyte-macrophage lineage are the C1q-producing sources in the spleen. Identification of specific cell types by in situ hybridization and immunohistochemical analysis. J Immunol 155:4971-4978.

Shapiro RA, Farrell L, Srinivasan M, Curthoys NP (1991) Isolation, characterization, and in vitro expression of a cDNA that encodes the kidney isoenzyme of the mitochondrial glutaminase. J Biol Chem 266:18792-18796.

Shepheard SL, Williamson DJ, Hill RG, Hargreaves RJ (1993) The non-peptide neurokinin1 receptor antagonist, RP 67580, blocks neurogenic plasma extravasation in the dura mater of rats. Br J Pharmacol 108:11-12.

Shigemoto R, Yokota Y, Tsuchida K, Nakanishi S (1990) Cloning and expression of a rat neuromedin $\mathrm{K}$ receptor cDNA. J Biol Chem 265:623-628

Shigemoto R, Nakaya Y, Nomura S, Ogawa MR, Ohishi H, Kaneko T, Nakanishi S, Mizuno N (1993) Immunocytochemical localization of rat substance P receptor in the striatum. Neurosci Lett 153:157-160.

Shughrue PJ, Lane MV, Merchenthaler I (1996) In situ hybridization analysis of the distribution of neurokinin-3 mRNA in the rat central nervous system. J Comp Neurol 372:395-414.

Somers DL, Beckstead RM (1990) Striatal preprotachykinin and preproenkephalin mRNA levels and the levels of nigral substance $\mathrm{P}$ and pallidal Met5-enkephalin depend on corticostriatal axons that use the excitatory amino acid neurotransmitters aspartate and glutamate: quantitative radioimmunocytochemical and in situ hybridization evidence. Brain Res Mol Brain Res 8:143-158.

Somogyi P, Tamas G, Lujan R, Buhl EH (1998) Salient features of synaptic organisation in the cerebral cortex. Brain Res Brain Res Rev 26:113-135.

Suzuki H, Abe K, Tojo S, Kimura K, Mizugaki M, Itoyama Y (1998) A change of P-selectin immunoreactivity in rat brain after transient and permanent middle cerebral artery occlusion. Neurol Res 20:463-469.

Tamura A, Graham DI, McCulloch J, Teasdale GM (1981) Focal cerebral ischaemia in the rat. 1. Description of technique and early neuropathological consequences following middle cerebral artery occlusion. J Cereb Blood Flow Metab 1:53-60.

Too HP, Marriott DR, Wilkin GP (1994) Preprotachykinin-A and sub- stance $\mathrm{P}$ receptor (NK1) gene expression in rat astrocytes in vitro. Neurosci Lett 182:185-187.

Urban L, Naeem S, Patel IA, Dray A (1994) Tachykinin induced regulation of excitatory amino acid responses in the rat spinal cord in vitro. Neurosci Lett 168:185-188.

Wang JQ, McGinty JF (1998) Metabotropic glutamate receptor agonist increases neuropeptide mRNA expression in rat striatum. Brain Res Mol Brain Res 54:262-269.

Wang X, Siren AL, Liu Y, Yue TL, Barone FC, Feuerstein GZ (1994) Upregulation of intercellular adhesion molecule 1 (ICAM-1) on brain microvascular endothelial cells in rat ischemic cortex. Brain Res Mol Brain Res 26:61-68.

Warden MK, Young WD (1988) Distribution of cells containing mRNAs encoding substance $\mathrm{P}$ and neurokinin $\mathrm{B}$ in the rat central nervous system. J Comp Neurol 272:90-113.

Weihe E, Nohr D, Muller S, Buchler M, Friess H, Zentel HJ (1991) The tachykinin neuroimmune connection in inflammatory pain. Ann NY Acad Sci 632:283-295.

Weihe E, Nohr D, Sharer L, Murray E, Rausch D, Eiden L (1993) Cortical astrocytosis in juvenile rhesus monkeys infected with simian immunodeficiency virus. NeuroReport 4:263-266.

Weihe E, Schäfer MK, Nohr D, Persson S (1994) Expression of neuropeptides, neuropeptide receptors and neuropeptide processing enzymes in spinal neurons and peripheral non-neuronal cells and plasticity in models of inflammatory pain. In: Neuropeptides, nociception and pain (Hökfelt T, Schmidt RF, Schaible HG, eds), pp 43-69. Weinheim, Germany: Chapman and Hall.

Wenk GL, Zajaczkowski W, Danysz W (1997) Neuroprotection of acetylcholinergic basal forebrain neurons by memantine and neurokinin B. Behav Brain Res 83:129-133.

Whitty CJ, Walker PD, Goebel DJ, Poosch MS, Bannon MJ (1995) Quantitation, cellular localization and regulation of neurokinin receptor gene expression within the rat substantia nigra. Neuroscience $64: 419-425$.

Wyborski RJ, Bond RW, Gottlieb DI (1990) Characterization of a cDNA coding for rat glutamic acid decarboxylase. Brain Res Mol Brain Res 8:193-198.

Yu Z, Cheng G, Huang X, Li K, Cao X (1997) Neurokinin-1 receptor antagonist SR140333: a novel type of drug to treat cerebral ischemia. NeuroReport 8:2117-2119.

Zachrisson O, Lindefors N, Brene S (1998) A tachykinin NK1 receptor antagonist, CP-122,721-1, attenuates kainic acid-induced seizure activity. Brain Res Mol Brain Res 60:291-295. 